SALMONID GAMETE

\title{
PRESERVATION IN THE
}

SNAKE RIVER BASIN

Annual Report 2000

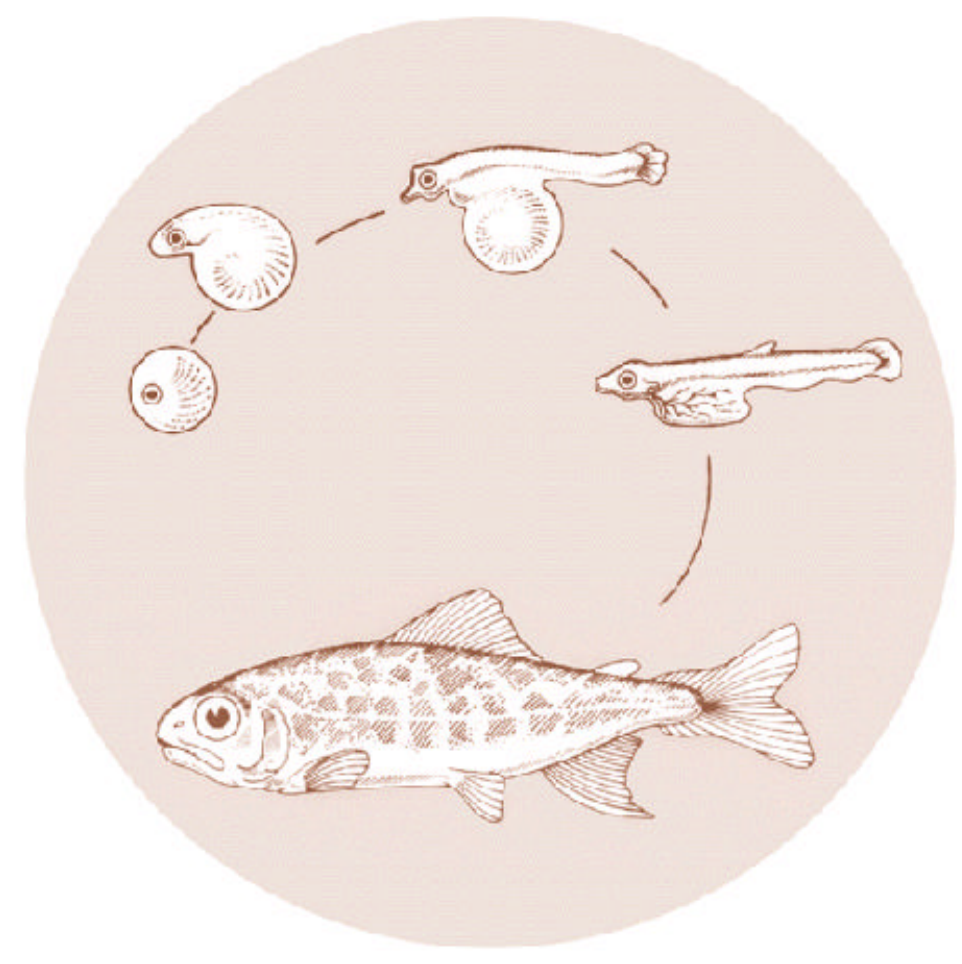

DOE/BP-00003047-1 
This report was funded by the Bonneville Power Administration (BPA), U.S. Department of Energy, as part of BPA's program to protect, mitigate, and enhance fish and wildlife affected by the development and operation of hydroelectric facilities on the Columbia River and its tributaries. The views of this report are the author's and do not necessarily represent the views of BPA.

This document should be cited as follows:

Kucera, Paul A., Robyn D. Armstrong - Nez Perce Tribe, 2001, Salmonid Gamete Preservation In The Snake River Basin 2000 Annual Report, Report, Report to Bonneville Power Administration, Contract No. 00003047, Project No. 199703800, 62 electronic pages (BPA Report DOE/BP-00003047-1)

This report and other BPA Fish and Wildlife Publications are available on the Internet at:

\section{http://www.efw.bpa.gov/cgi-bin/efw/FW/publications.cgi}

For other information on electronic documents or other printed media, contact or write to:

Bonneville Power Administration

Environment, Fish and Wildlife Division

P.O. Box 3621

905 N.E. 11th Avenue

Portland, OR 97208-3621

Please include title, author, and DOE/BP number in the request. 


\section{SALMONID GAMETE PRESERVATION IN THE SNAKE RIVER BASIN}

\section{Annual Report}

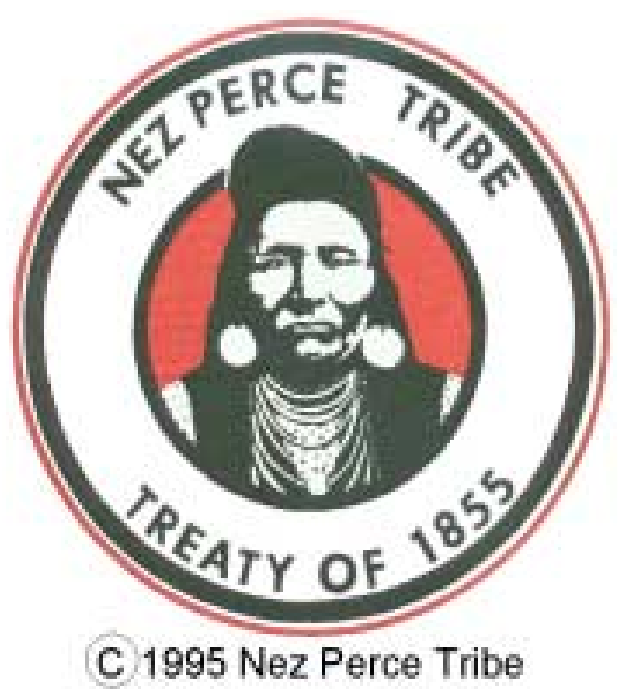

Prepared by:

Robyn D. Armstrong

Paul A. Kucera

Nez Perce Tribe

Department of Fisheries Resources Management

P.O. Box 365

Lapwai, Idaho 83540

June 2001 


\title{
Salmonid Gamete Preservation in the Snake River Basin
}

2000 Annual Report

\author{
Prepared by: \\ Robyn D. Armstrong \\ Paul A. Kucera \\ Nez Perce Tribe \\ Department of Fisheries Resources Management \\ Lapwai, Idaho 83540
}

Prepared for:

U.S. Department of Energy

Bonneville Power Administration

Environment, Fish and Wildlife

P.O. Box 3621

Portland, Oregon 97208-3621

Project Number 97-03800

Contract Number 97-AM30423

Task Order Number 97-AT35208

and

U.S. Fish and Wildlife Service

Lower Snake River Compensation Plan

1387 South Vinnell Way, Suite 343

Boise, Idaho 83709

Cooperative Agreement Number 141100J006

June 2001 


\begin{abstract}
Steelhead (Oncorhynchus mykiss) and chinook salmon (Oncorhynchus tshawytscha) populations in the Northwest are decreasing. Genetic diversity is being lost at an alarming rate. The Nez Perce Tribe (Tribe) strives to ensure availability of genetic samples of the existing male salmonid population by establishing and maintaining a germplasm repository. The sampling strategy, initiated in 1992, has been to collect and preserve male salmon and steelhead genetic diversity across the geographic landscape by sampling within the major river subbasins in the Snake River basin, assuming a metapopulation structure existed historically. Gamete cryopreservation conserves genetic diversity in a germplasm repository, but is not a recovery action for listed fish species.

The Tribe was funded in 2000 by the Bonneville Power Administration (BPA) and the U.S. Fish and Wildlife Service Lower Snake River Compensation Plan (LSRCP) to coordinate gene banking of male gametes from Endangered Species Act listed steelhead and spring and summer chinook salmon in the Snake River basin. In 2000, a total of 349 viable chinook salmon semen samples from the Lostine River, Catherine Creek, upper Grande Ronde River, Lookingglass Hatchery (Imnaha River stock), Rapid River Hatchery, Lake Creek, the South Fork Salmon River weir, Johnson Creek, Big Creek, Capehorn Creek, Marsh Creek, Pahsimeroi Hatchery, and Sawtooth Hatchery (upper Salmon River stock) were cryopreserved. Also, 283 samples of male steelhead gametes from Dworshak Hatchery, Fish Creek, Grande Ronde River, Imnaha River, Little Sheep Creek, Pahsimeroi Hatchery and Oxbow Hatchery were also cryopreserved. The Tribe acquired 5 frozen steelhead samples from the Selway River collected in 1994 and 15 from Fish Creek sampled in 1993 from the U.S. Geological Survey, for addition into the germplasm repository. Also, 590 cryopreserved samples from the Grande Ronde chinook salmon captive broodstock program are being stored at the University of Idaho as a long-term archive, half of the total samples. A total of 2,420 cryopreserved samples from Snake River basin steelhead and spring and summer chinook salmon, from 1992 through 2000, are stored in two independent locations at the University of Idaho and Washington State University. Two large freezer tanks are located at each university, each of which holds approximately $25 \%$ of the cryopreserved sperm. One tank at each university is considered long-term archival storage, while the other is short-term.
\end{abstract}

Fertility trials were conducted at each university to test the viability of the cryopreserved chinook salmon sperm. The experiments on the 2000 frozen and thawed sperm at both universities found a fertility rate of $60-70 \%$.

This document also summarizes 1999-2000 steelhead genetic analysis report. The results of mitochondrial, nuclear DNA and microsatellite analysis found differences and shared haplotypes between the stocks of fish sampled for cryopreservation.

Recommendations for future gene banking efforts include the need for establishment of a regional genome resource bank, a greater emphasis on cryopreserving wild fish, continued fertility trials, exploring field cryopreservation and genetic analysis on all fish represented in the germplasm repository. 


\section{TABLE OF CONTENTS}

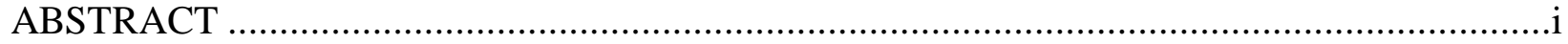

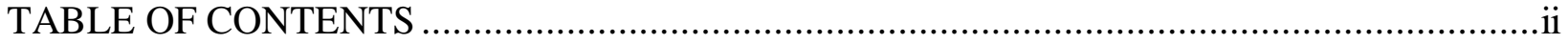

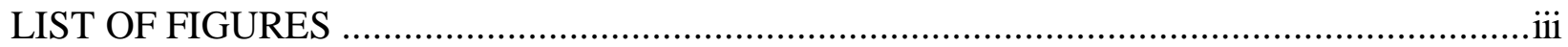

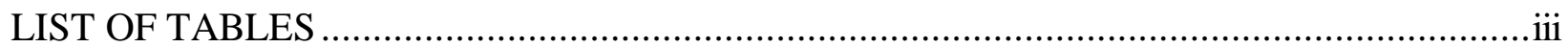

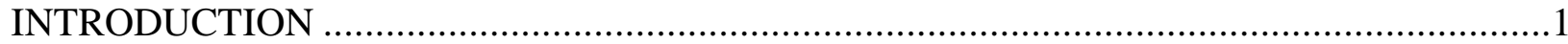

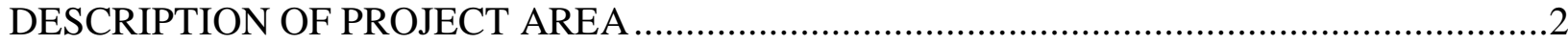

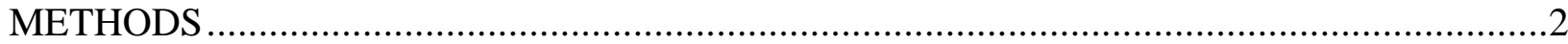

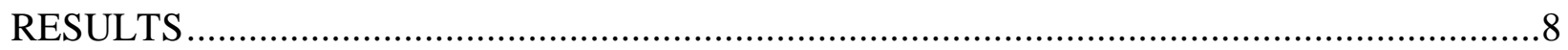

Description of Spawning Aggregates ...................................................................

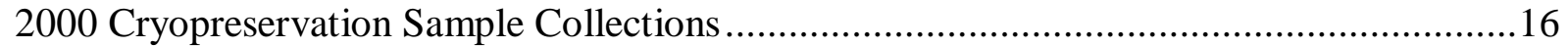

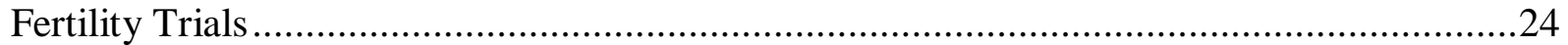

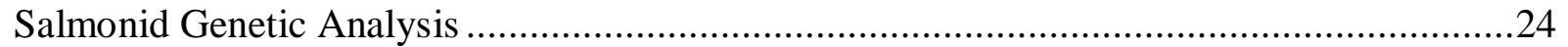

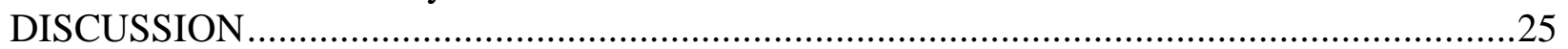

Other Gene Banking Efforts in the Snake River Basin..................................................2

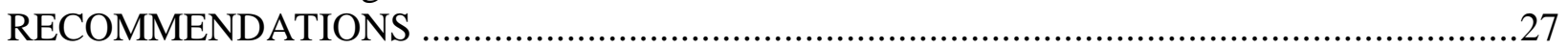

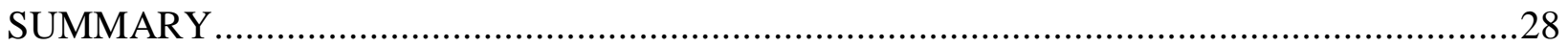

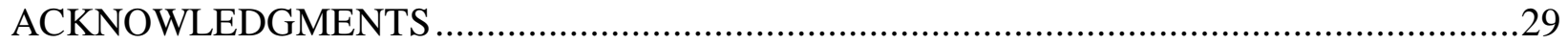

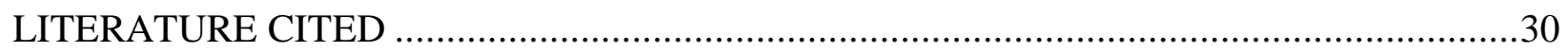

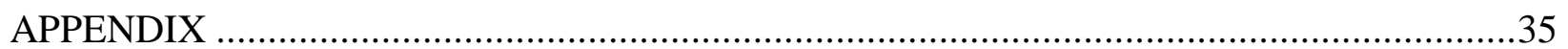

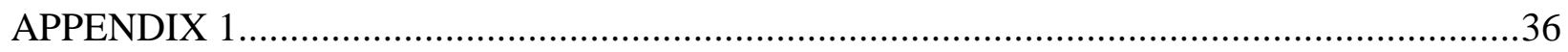

APPENDIX 2. Snake River Germplasm Repository Cryopreserved Semen Request Form ......41

APPENDIX 3. Genetic Diversity in Oncorhynchus mykiss from the Snake River Basin and Eastern Oregon. 


\section{LIST OF FIGURES}

Figure 1. Snake River basin chinook salmon and steelhead cryopreservation locations in 2000. .2 Figure 2. Collecting chinook salmon milt from anaesthetized fish at Big Creek......................4

Figure 3. Anaesthetized male chinook salmon on portable tank for measurements....................5

Figure 4. Conducting pre-freeze motility estimates on fresh chinook salmon sperm.................6

Figure 5. Example of a liquid nitrogen tank where chinook salmon and steelhead germplasm is stored.

Figure 6. Length frequency distribution of male chinook salmon sampled for cryopreservation in

Johnson Creek in 2000.

Figure 7. Length frequency distribution of hatchery and natural male chinook salmon sampled

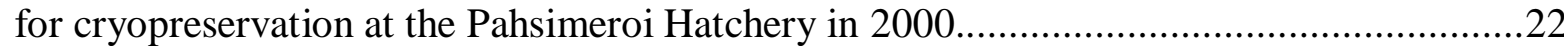

Figure 8. Length frequency distribution of hatchery and natural male steelhead sampled for cryopreservation in Little Sheep Creek in 2000.

Figure 9. Length frequency distribution of hatchery and natural male chinook salmon sampled

for cryopreservation in the Imnaha River in 2000.

\section{LIST OF TABLES}

Table 1. Broodstock history of Lookingglass Hatchery Grande Ronde spring chinook salmon .10 Table 2. South Fork Salmon River summer chinook salmon releases in Johnson Creek .....

Table 3. Snake River basin spring and summer chinook salmon spawning aggregates sampled for semen collection in 2000. Includes total samples cryopreserved, unmarked (wild/natural) and marked (hatchery) fish numbers, dates collected, and the range of percent sperm motility.

Table 4. Snake River basin steelhead spawning aggregates sampled for semen collection in 2000. Includes total samples cryopreserved, unmarked (wild/natural) and marked (hatchery) fish numbers, dates collected, and the range of percent sperm motility................................. 18 Table 5. Snake River basin chinook salmon cryopreserved from 1992-2000...........................37

Table 6. Snake River basin steelhead cryopreserved in 1997-2000. .......................................38 Table 7. Total number of cryopreserved samples taken from Snake River basin spring / summer chinook and steelhead and the number of $0.5 \mathrm{ml}$ and $5.0 \mathrm{ml}$ straws in storage from 1992-2000. 39 Table 8. Summary of Gene Bank Fertility Experiments in 2000 at Washington State University and University of Idaho. 


\section{INTRODUCTION}

Snake River steelhead (Oncorhynchus mykiss) and spring and summer chinook salmon (Oncorhynchus tshawytscha) spawning aggregates have experienced significant decline in numbers over the past five decades. These species are now listed as threatened under the ESA. These declines are due to many different factors. Most are the result of human activities.

Genetic conservation through population protection and monitoring has not been successful. With the constant threat of losing genetic diversity in specific native fish stocks, the establishment of a program for the long-term storage of fish germplasm serves as insurance against population collapse and extirpation. The Tribe has ensured the preservation of genetic diversity through cryopreservation of male gametes and development of a germplasm repository. At present, cryopreservation of semen is the best means of storing fish germplasm for extended periods of time. Cryopreserved salmonid semen will remain viable for long periods and can be easily shipped. Ashwood-Smith (1980), Whittingham (1980), and Stoss (1983) have estimated the storage time for fish semen held in liquid nitrogen to be between 200 and 32,000 years. This storage period is more than adequate for a germplasm repository. Although preservation of the maternal nuclear DNA component has been accomplished with some mammals (Rall and Fahy 1985, Fahning and Garcia 1992, Dobrinsky et al. 1991, Ali and Shelton 1993, Kono et al. 1988, Trounson and Mohr 1983, Hayashi et al. 1989), no similar techniques exist for fish species. Successful research and development to preserve germplasm components from female salmonids would increase future management options.

There are two important factors to be considered when developing a germplasm repository. First, this is a genetic repository and will not solve population problems of a fish stock that is at low levels of abundance and high risk of localized extinction. Second, fertility of the stored semen currently is not as great as the fresh semen. The quality of the stored semen is usually a direct reflection of the quality of the sperm that was cryopreserved, and $50 \%$ motility of fresh sperm is considered good. There is a risk of lower fertilization rates and potential loss of eggs using cryopreserved semen. The Tribe, University of Idaho (UI) and Washington State University (WSU) conducted a small-scale fertilization trial using non-listed chinook salmon 2000 cryopreserved sperm and fresh eggs and sperm from Dworshak National Fish Hatchery and Lyons Ferry Hatchery, respectively.

The Nez Perce Tribe initiated chinook salmon cryopreservation activities in 1992 (Armstrong and Kucera 2000). The Lower Snake River Compensation Plan hatchery evaluation program funding through the U.S. Fish and Wildlife Service has provided a valuable, though limited, amount of financial support for this effort from 1992 through 2000. Bonneville Power Administration funded the Nez Perce Tribe in 1997 to coordinate and initiate a more comprehensive gene banking effort (Faurot et al. 1998). More extensive male steelhead gamete cryopreservation was initiated in 1999 (Armstrong and Kucera 1999).

Goals of the cryopreservation project are: 1) preserve the genetic diversity of listed salmonid populations at high risk of extirpation through application of cryogenic techniques, 2) maintain gene bank locations at independent sites for the short-term, and 3) establish and maintain longterm germplasm repositories. 


\section{DESCRIPTION OF PROJECT AREA}

The cryopreservation project currently seeks to preserve male spring and summer chinook salmon and steelhead gametes. The project area is the Snake River basin (Figure 1). In 2000, the sampling locations included: Dworshak National Fish Hatchery, Lostine River, Catherine Creek, upper Grande Ronde River, Imnaha River, Lookingglass Hatchery (Imnaha River spawning aggregate), Little Sheep Creek, Rapid River Hatchery, Lake Creek, Johnson Creek, South Fork Salmon River (SFSR), Big Creek, Capehorn Creek, Marsh Creek, Pahsimeroi Hatchery, Sawtooth Hatchery (upper Salmon River spawning aggregate) and Oxbow Hatchery. Lapwai Office and Enterprise Field Offices cost share fisheries personnel as well as the McCall Field Office to successfully begin to cover this geographically large collection area.

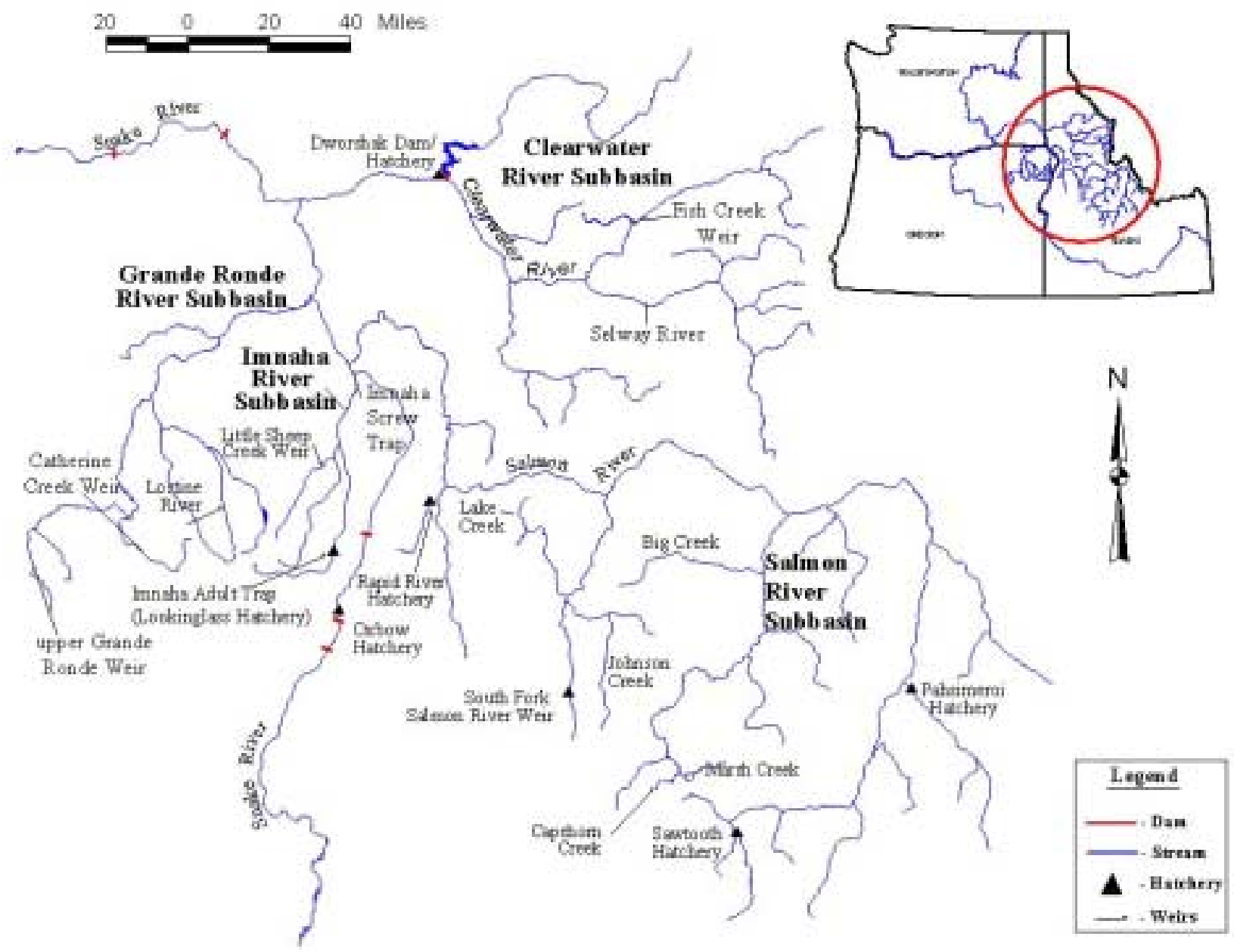

Figure 1. Snake River basin chinook salmon and steelhead cryopreservation locations in 2000.

\section{METHODS}

Fish handling protocol training was provided to all personnel prior to collection of adult male salmonids to minimize stress on the fish. Each team member was assigned a specific duty to improve the efficiency of sample collection. Semen from male kelts was collected from fish on 
the spawning grounds or from hatchery holding ponds. Fish were captured either by hand or dip net in the streams and sampled for sperm.

Chinook salmon spawning ground surveys are usually conducted on pre-determined stream reaches before handling any fish. Redd counts also determine where in each stream the collection of adult males occurs. Several team members locate the adults, being careful not to disturb the fish. Observations are made to visually identify male salmon. Males are identified by secondary sexual characteristics, which include a kype (greatly extended, narrowed snout, turned down at tip, also an enlarged lower jaw), large teeth, and a slim caudal peduncle that is not as worn as the female salmon. Females can be identified by a rounder head, thicker caudal peduncle, and a tattered, discolored (white) caudal fin from digging the redds. No harassment of actively spawning salmon or steelhead occurs.

No one enters the water near any existing or active redds (i.e. where salmon are on the nests). A snorkeler enters the water to find solitary males, looking under cut banks, in logjams, in backwater habitats, etc. From the vantage point underwater, this person identifies fish for others to collect. It is easiest to collect the males in a constricted portion of the stream. Any females caught are returned to the water immediately, unharmed, and the capture is recorded.

All adult male salmon sampled are collected by hand, dip net, or seine in that order of priority: Hand. Walk or swim up to the identified fish and grasp the fish at caudal peduncle, put the fish into a dip net immediately. Always keep the fish in the water, pointing upstream, until ready to place in the tank.

Dip net. Stay away from active redds. Several dip netters get into position below the fish, with several people in the water upstream of the fish. The upstream people slowly herd fish towards the netters. Keep the large dip nets in the water in a line and let fish swim into the net. Net holders should be absolutely still as fish approach the nets.

Seine. Two 5' x 30-40' seine nets are set up perpendicular to the flow of water, blocking a segment of stream. The upstream net is moved slowly downstream, trapping the fish in a corral of decreasing area. Fish are collected with dip nets. If more than one fish is captured, determine which fish are to be sampled and release the others immediately.

Upon capture of the male, the anesthetic bath tank is set up and filled. Captured fish are held in the stream before transfer to the anesthetic bath tank. General anesthetics first calm the fish, then cause it successively to lose mobility, equilibrium, consciousness, and finally reflex action (Summerfelt and Smith 1990). We wish to immobilize adult male salmon so they can be handled faster and less stressfully. A portable 35-gallon tank is set up along the stream to anaesthetize male chinook. Two people set up and fill the portable tank with seven 5-gallon buckets. Pre-measured Finquel ${ }^{\mathrm{TM}}$, tricane methanesulfonate (MS-222), is used to anesthetize the adult male salmon, with the exception of hatchery fish. Sodium bicarbonate $\left(\mathrm{NaHCO}_{3}\right)$ is used to buffer the acidic effect of the MS-222. It takes 1-3 minutes for the fish to be anesthetized. It is important to have one person time how long the fish is in the tank, and observe the fish all the time it is undergoing anesthesia. Fish handling/spawning protocols of Idaho Department of Fish and Game (IDFG) are used at the Idaho hatcheries, and the adults are not anesthetized before semen samples are taken. Imnaha River chinook salmon are anesthetized at Lookingglass Hatchery. Extra care is taken with semen collection to ensure the quality of 
preserved samples. The sedated fish is rinsed in the fresh water of the stream before milt is collected. The abdomen of the anesthetized male chinook salmon is dried to reduce contamination of the semen samples and the milt is sampled (Figure 2).

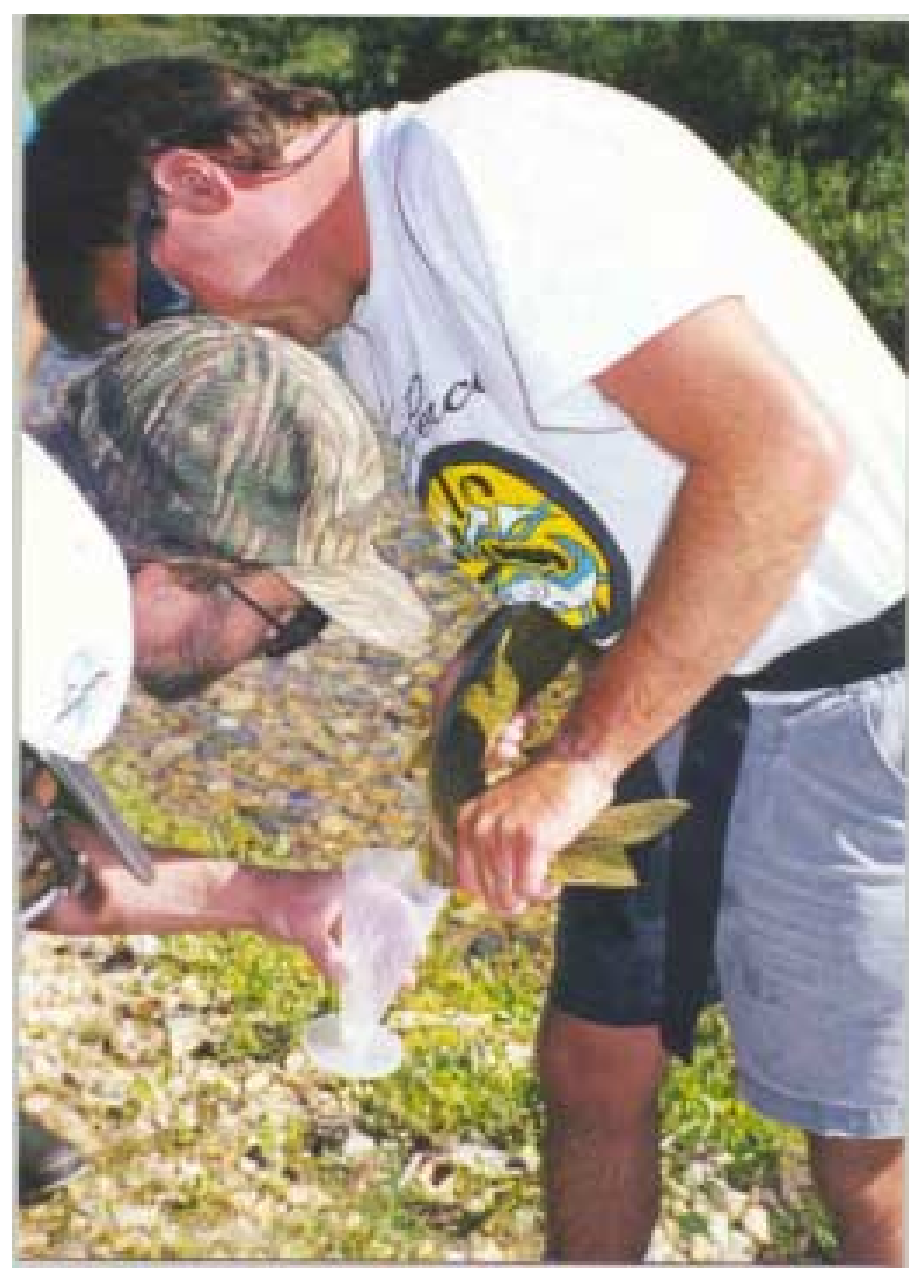

Figure 2. Collecting chinook salmon milt from anaesthetized fish at Big Creek.

Semen samples were placed in two separately labeled Whirl Pak bags, aerated, and placed in an insulated cooler, on newspaper over wet ice. Some of the fish provide only enough semen for cryopreservation at one university. A few males are completely spawned out, so samples are not obtained. After the fish is released into the stream, the tank is emptied well away from the stream, so no chemicals are released into the stream proper. Fish biological information (fork length and mid-eye to hypural plate length, general condition, external marks) was recorded following semen collection (Figure 3). Caudal fin tissue was collected and preserved in ethyl alcohol for later genetic (DNA) analysis. Scales were taken for age assessment and scale pattern analysis. Following sampling and data collection, the anesthetized salmon were immediately returned to a slow water area and assisted until recovered. 


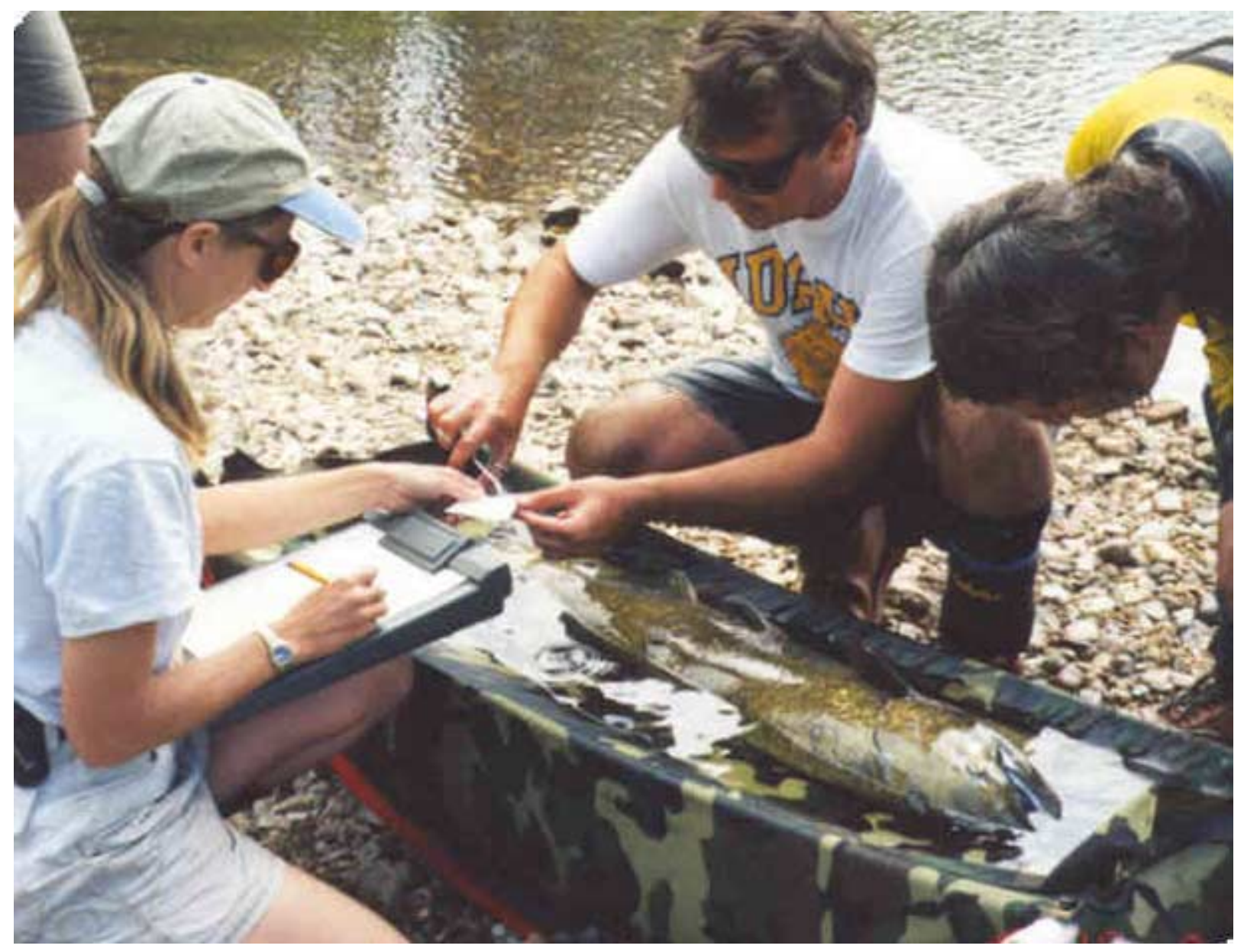

Figure 3. Anaesthetized male chinook salmon on portable tank for measurements.

Semen samples are shipped to, cryopreserved and stored at each university as a safeguard to protect against catastrophic events that could destroy all germplasm samples if they were stored at one facility. Cryopreservation and storage occur independently at UI and WSU within a 12hour period. Both universities started using nitrogen vapor freezing techniques in 1997 . These samples were frozen in $200.5 \mathrm{~mL}$ French straws (IMV International, Minneapolis, Minnesota) if the quantity allowed. Any excess semen was cryopreserved in larger $5.0 \mathrm{ml}$ straws. We continue to enlist the assistance of Dr. Joseph Cloud, professor of Zoology in the Department of Biological Sciences at the University of Idaho, Dr. Gary Thorgaard and Paul Wheeler in the Thorgaard Lab at Washington State University, and Dr. Madison Powell, geneticist at the Fish Genetics Laboratory and Hagerman Experiment Station with the University of Idaho. These subcontractors are experts in the field of salmonid cryopreservation, reproductive physiology and/or fish genetics.

Sperm evaluation is an important component of the cryopreservation program in order to estimate the quality from the motility of the stored sperm. All semen from listed fish is stored regardless of motility. Fertility is evaluated by sperm motility (Figure 4), which is the percentage of motile sperm following the addition of a sperm activating solution (Mounib 1978). Motility correlates to post-thaw fertility. 


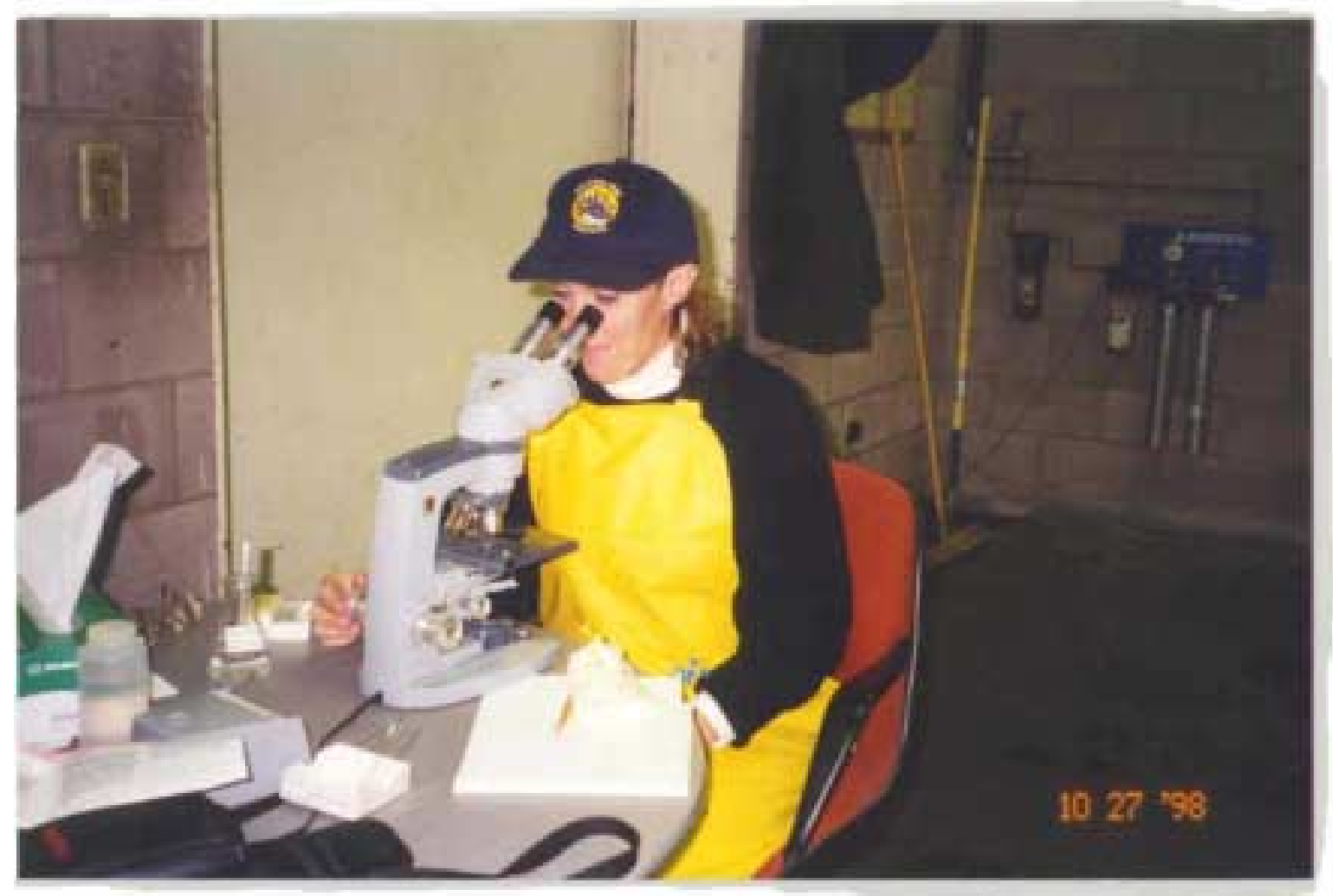

Figure 4. Conducting pre-freeze motility estimates on fresh chinook salmon sperm.

There are four stages in the cooling sequence of cryopreservation of cells (Cloud and Osborne 1997): 1) Cooling cells to the point of ice formation - this does not appear to be a critical factor in the cryopreservation of salmonid sperm; 2) The formation of ice - the goal at this stage is to have ice form near the freezing point of the extracellular solution; 3) Cooling through the critical period - there is a net movement of water out of the cells as the temperature is constantly being reduced 4) Reduction to liquid nitrogen temperature - the frozen milt is then plunged into liquid nitrogen at $-196^{\circ} \mathrm{C}$.

The amount of sperm cryopreserved varied greatly by individual fish and by species. Chinook salmon produce greater volumes of milt (averaging $15 \mathrm{ml}$ ), whereas steelhead produce less (average 2-4 ml). A sample of $5 \mathrm{ml}$ of semen is sufficient to fill $200.5 \mathrm{ml} \mathrm{straws}$, due to the dilution of semen with three parts freezing solution. Depending on the motility of the thawed sperm, one $0.5 \mathrm{ml}$ straw can fertilize up to 450 eggs, and a $5.0 \mathrm{ml}$ straw can fertilize approximately 2,000 eggs. There is not a linear relationship of straw volume to fertilization capacity due to the heat of fusion and the surface area involved. Two additional large liquid nitrogen tanks, one for each university, were purchased in late 1998 to serve as emergency backups and long-term repositories. Each university now has two large nitrogen storage facilities, which became operational in 1999 (Figure 5). These tanks are nearly full and will be after the 2001 field seasons. More tanks will be necessary then. 


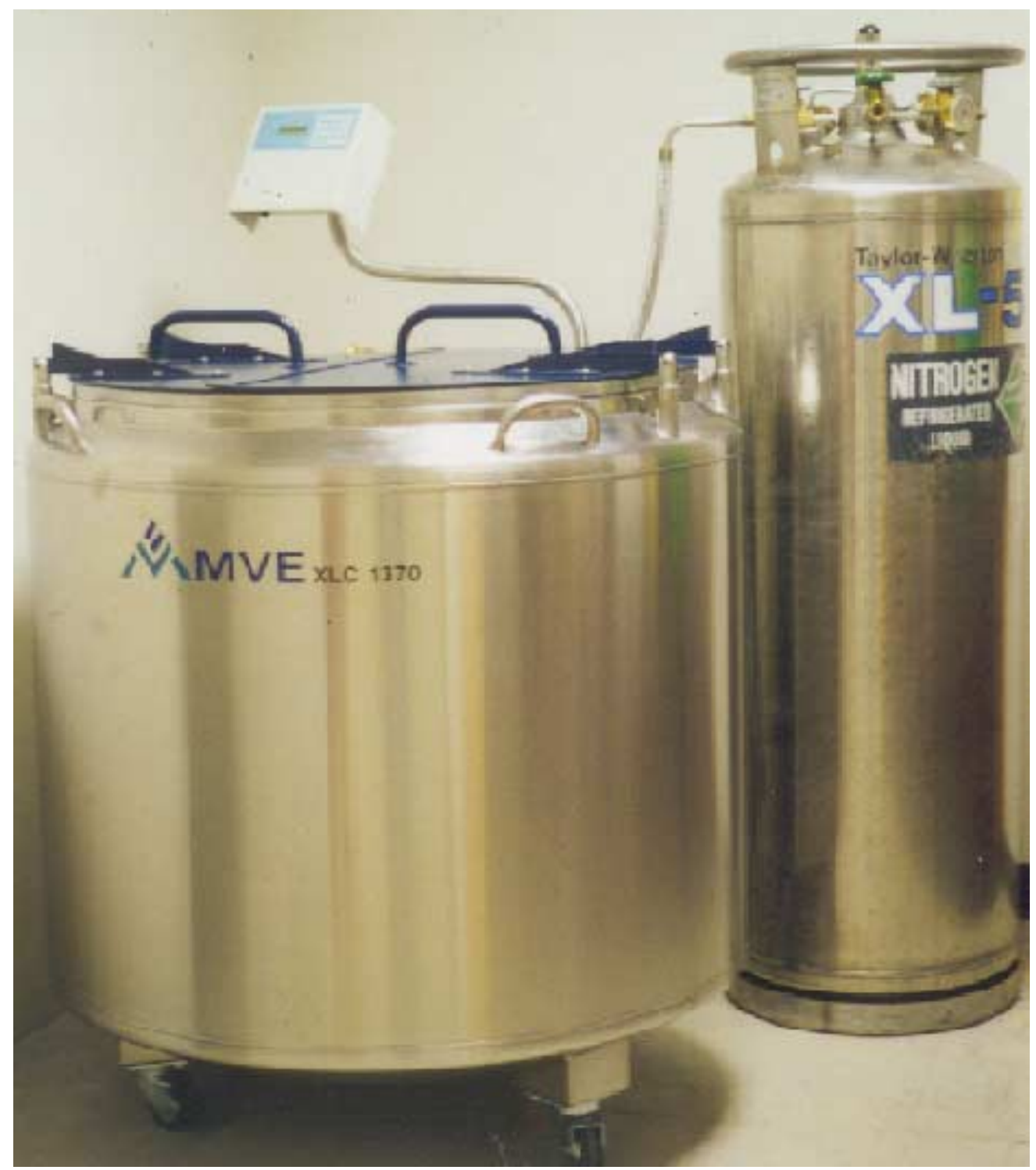

Figure 5. Example of a liquid nitrogen tank where chinook salmon and steelhead germplasm is stored.

Fertilization experiments have been conducted every year on chinook salmon cryopreserved versus fresh sperm in order to assess our procedures. In 2000, Washington State University pooled the chinook salmon eggs in the fertilization trial. Semen from five gene banked chinook males was used to fertilize the pooled eggs. Milt in a $0.5 \mathrm{~mL}$ straw was used from each of the five males tested three times (for 15 different family groups). University of Idaho thawed four different hatchery male gamete samples and each sample fertilized Dworshak Hatchery chinook eggs. 


\section{RESULTS}

\section{Description of Spawning Aggregates}

The background of the selected spawning aggregates for cryopreservation activities have a diverse history of transfers, stocking, and straying. Chinook salmon and steelhead hatcheries in the Snake River basin that are sampled for male gamete cryopreservation have developed broodstocks in a variety of ways. It is important to understand how broodstock development, management and stocking occurred as it relates to the genetic profile of the existing stock of fish being propagated in these facilities. A genetic analysis was not conducted on any of the original hatchery or stream brood sources to the authors' knowledge. In that regard, we have compiled existing information of where the original chinook salmon and steelhead spawning aggregates brood sources were obtained.

\section{Grande Ronde River}

The Grande Ronde River is located in northeast Oregon and historically supported diverse and healthy populations of summer steelhead and spring chinook salmon (Carmichael et al 1998b). Summer steelhead in the Grande Ronde basin is supplemented with Wallowa stock fish from three Lower Snake River Compensation Plan (LSRCP) facilities in Oregon. The hatchery program began in 1976 with the collection of adults trapped at Ice Harbor Dam and Little Goose Dam in 1977 and 1978. It is not clear whether steelhead adults collected at these dams were destined for the Grande Ronde River basin. In 1979, embryos from Pahsimeroi Fish Hatchery in Idaho were incorporated into the broodstock. In addition, relatively few fish were used to develop the Wallowa stock of steelhead. To meet broodstock needs in 1991 and 1995, ODFW incorporated Wallowa stock adults returning to Cottonwood Creek, Washington into the hatchery program. Furthermore, since the Wallowa stock was founded it has generally been domesticated through inbreeding. Thus, Wallowa stock steelhead and steelhead produced naturally in the Grande Ronde River basin may not be similarly adapted to the local conditions in this basin (Whitesel et al 1998).

The Oregon Fish Commission built a dam on the Wallowa River downstream from the confluence with the Minam River in 1904, which was operational in 1905 and the permanent rock crib dam was in place in 1906 (Oregon Fish Commission 1906). It is assumed that this structure was at least a partial, if not a permanent barrier to anadromous fish passage through the 1920s (Don Bryson NPT personal communication). The dam was for broodstock collections and spawning at a nearby hatchery. Because of freezing conditions in the hatchery in the winter, fry were released in the river at this time (Don Bryson NPT personal communication). The dam was partially destroyed in the 1920s allowing fish to pass upstream and recolonize unseeded areas (Don Bryson NPT personal communication).

Oregon Fish Commission moved approximately four to five million McKenzie River (a tributary to the Willamette River) chinook salmon eggs into the Wallowa Hatchery in 1927 and other years. These fish were released as five-inch fish into Wallowa River (Don Bryson NPT personal communication). 
ODFW and the Umatilla Tribe operate an adult weir on the upper Grande Ronde River, Catherine Creek and the Lostine River as part of the conventional chinook salmon hatchery program at Lookingglass Fish Hatchery. Several downstream migrating steelhead were captured and male kelts can be sampled from this weir.

\section{Grande Ronde Subbasin Chinook Salmon Captive Broodstock Project}

A Grande Ronde basin spring chinook salmon captive broodstock program was initiated in 1995 with the collection of juvenile salmon (500 parr) from the Lostine River, Catherine Creek and upper Grande Ronde River. Fish are reared at Lookingglass Fish Hatchery until the smolt stage and then are transferred to facilities at Bonneville Hatchery $(\mathrm{BOH})$ and Manchester Marine Laboratory (MML). This allows for the evaluation of freshwater and saltwater broodstock rearing strategies. As the fish reach maturity, the MML fish are moved to $\mathrm{BOH}$ where they are held until they ripen and are spawned, and/or died. This program is an attempt to maximize the species reproductive potential and to preserve the population through use of acclimated smolt releases to return a threshold number of spawning chinook salmon adults to the three rivers (Harbeck personal communications). Excess milt is cryopreserved from the male chinook salmon towards the end of the spawning season to have a repository of genetic material available from these captive fish. One half of each sperm sample is stored at the University of Idaho germplasm repository as a safeguard should anything happen to the storage facility at $\mathrm{BOH}$.

In previous years, portions of the Rapid River stock and Carson River (82-89) stock maintained in the Lookingglass Hatchery were released into the Upper Grande Ronde River, Wallowa River, Catherine Creek, and into Lookingglass Creek itself (Crateau 1995).

The release of Rapid River stock as well as Carson River stock has resulted in an extremely high incidence of straying in the Grande Ronde Basin. In some years and at some localities, stray hatchery fish represented 35-100\% of the fish found in a particular area. Most recent spawningground surveys revealed a considerable amount of straying. For example, in 1990, stray hatchery fish constituted an estimated $46.2 \%$ of the spawners in the Minam River, $77.8 \%$ in the Wenaha River, $40 \%$ in the Lostine River, 100\% in Catherine Creek, and 50\% in the Grande Ronde River. In 1992, the amount of straying was particularly high, probably because of low water levels that may have prevented access to some spawning areas. In 1993, straying was somewhat lower, but still over $45 \%$ in all populations (Carmichael 1998b).

\section{$\underline{\text { Lostine River }}$}

The Lostine River is a tributary to the Wallowa River in the Grande Ronde subbasin in northeast Oregon. The Oregon Fish Commission built a dam on the Wallowa River downstream from the confluence with the Minam River in 1904, which was operational in 1905 and a permanent rock crib dam was in place in 1906 (Oregon Fish Commission 1906). It is assumed that this structure was at least a partial, if not a permanent barrier to Lostine River anadromous fish passage through the 1920s (Don Bryson NPT personal communication). The dam was partially destroyed in the 1920s allowing fish to pass upstream and recolonize unseeded areas (Don Bryson NPT personal communication). There have not been any deliberate outplants of chinook salmon into the Lostine River (Don Bryson NPT personal communications). 
Straying of Grande Ronde chinook salmon hatchery fish from Lookingglass Hatchery occurs in the Lostine River. Based on the origin of carcasses recovered on spawning ground surveys, ODFW determined that a high proportion (20-75\%) of natural spawners in the Lostine River were of Lookingglass Hatchery origin from 1986-1994 (Carmichael et al. 1998b). The broodstock history at Lookingglass Hatchery is varied and complex (Table 1).

Table 1. Broodstock history of Lookingglass Hatchery Grande Ronde spring chinook salmon (Carmichael et al. 1998b).

\begin{tabular}{cc}
\hline Brood Year & Source \\
\hline 1978 & Rapid River \\
$1980-1984$ & Carson / Willamette Hatchery \\
$1985-1987$ & Carson / Lookingglass Hatchery \\
& Rapid River \\
1988 & Rapid River \\
1989 & Carson / Lookingglass Hatchery \\
& Rapid River \\
$1990-1997$ & Rapid River / Lookingglass Hatchery \\
$1995-2000$ & native Lostine, upper Grande Ronde, \\
& Catherine Creek \\
\hline
\end{tabular}

Since 1995, up to 50 adults from weirs on the Lostine River, upper Grande Ronde River and Catherine Creek have been collected, transported and spawned for the conventional hatchery program at Lookingglass Hatchery. Conventional supplementation means using endemic broodstock that return to a natal stream, spawning the adults in the hatchery, raising their progeny to smolt size, then returning them to their natal stream for volitional outmigration (Carmichael 1998b). Jack chinook salmon returned to the Lostine River from the conventional program in 2000.

Dworshak National Fish Hatchery (North Fork Clearwater River)

Dworshak National Fish Hatchery is located at the confluence of the North Fork and the main stem of the Clearwater River near Ahsahka, Idaho. The U.S. Army Corps of Engineers, as mitigation for Dworshak Dam, which blocks anadromous fish passage to the North Fork Clearwater River, built Dworshak National Fish Hatchery (DNFH) in 1969. The steelhead broodstock was started from native B-run steelhead returning to the North Fork to spawn (Howell et al. 1985b, IDFG et al. 1990, Rhine 1998). Based on allele frequencies, Milner (1997) 
reported that North Fork Clearwater steelhead were distinguishable from all other Columbia Basin steelhead by the high frequency of the allele for peptidase locus. Spawning stock is comprised of three age classes; I-, II-, and III- "salt" fish. This nomenclature refers to the number of complete years fish have spent in saltwater. Fish are actually two years older than this system indicates, as they are reared for one year in the hatchery and spend another year migrating to and from the ocean (Burge et al 2000). The DNFH is operated during the fall to insure inclusion of sufficient early arriving steelhead ( 500 adults) into the hatchery gene pool. The trap is then reopened from February through April to capture broodstock from the mid and late portions of the run (Burge et al 2000). The 1999-2000 return marked the $28^{\text {th }}$ year that artificially spawned North Fork Clearwater River steelhead have returned to DNFH (Burge et al 2000). At present, the Dworshak NFH population is considered to be part of the Snake River ESU. As such, Dworshak Hatchery steelhead fish are ESA-listed as threatened. The Biological Review Team concluded that the Snake River Basin steelhead ESU is not presently in danger of extinction, but it is likely to become endangered in the foreseeable future (Busby et al. 1996).

\section{Selway River}

The Selway and Lochsa rivers converge to form the Middle Fork Clearwater River in central Idaho. The Selway River is designated as a wild and scenic river. There is no history of any steelhead ever being stocked in the Selway River. Lewiston Dam was built at the mouth of the mainstem of the Clearwater River in 1927. This structure prevented passage of spring, summer and fall chinook salmon from at least 1927 to 1940, although steelhead was evidently able to pass (Milner 1997). Steelhead, which managed to hang on during the dam building era, is no longer abundant nor distributed as widely.

\section{$\underline{\text { Fish Creek }}$}

Fish Creek is a tributary to the Lochsa River in the upper Clearwater subbasin in northeast Idaho. Fish Creek had 80,000 Dworshak B-run steelhead fry stocked into it in 1979 and 20,000 in 1980 and nothing since. There have been numerous out plants in the Lochsa system (tributaries and mainstem) in the 70s and early 80s, but the last record of Dworshak stocking in the Lochsa drainage is in 1982.

\section{$\underline{\text { Rapid River Hatchery (Rapid River) }}$}

Rapid River is a tributary to the Little Salmon River south of Riggins in central Idaho. The Little Salmon River joins the Salmon River approximately 5 miles downstream from the Rapid River confluence. Rapid River Hatchery was constructed in 1964 through the Idaho Power Company (IPC) as part of the mitigation for spring chinook salmon losses due to the construction and operation of Brownlee Dam, Oxbow Dam, and Hells Canyon Dam on the Snake River (IDFG et al. 1990, Howell et al. 1985). Broodstock was obtained from adult collection at Hells Canyon Dam from 1964 through 1968. These fish originated from the mid-Snake River tributaries such as Eagle Creek, Powder River and the Weiser River (Howell et al. 1985a, IDFG et al. 1990). As such, this hatchery brood source represents the genetic diversity contained from these chinook salmon subpopulations. In addition, the hatchery broodstock probably contains natural spring and summer chinook salmon from Rapid River. 


\section{$\underline{\text { Lake Creek }}$}

Lake Creek and Summit Creek converge to form the Secesh River in central Idaho near Burgdorf. The Secesh River summer chinook run is a wild native run (Kiefer et al. 1996). Welsh and Corley (1968) reported that 112 adult summer chinook were transplanted into Summit Creek in 1966. The fish were hauled from the adult trap below Hells Canyon Dam into an area of Summit Creek blocked by a barrier, which was subsequently removed. Frequent observations of the transplanted fish revealed only 10 redds, there was no further information regarding evidence of spawning success or any resulting population. One hundred and eighty nine redds were counted in parts of the spawning areas of the Secesh River drainage that year (Kiefer et al. 1996).

Straying of hatchery fish (missing an adipose fin), presumably from McCall Fish Hatchery (MFH) South Fork Salmon River (SFSR) program has been noted in Lake Creek and the Secesh River. This is an infrequent occurrence on the order of 1-2 chinook salmon per year (Kucera and Blenden 1999).

\section{$\underline{\text { Johnson Creek }}$}

Johnson Creek is a tributary of the East Fork South Fork Salmon River in central Idaho near the town of Yellow Pine. The Johnson Creek summer chinook salmon population has received supplementation outplants of SFSR summer chinook salmon reared at MFH in 1984 through 1988 (Table 2). These outplants primarily occurred as fingerling releases and were distributed from the headwater reaches to the Ice Hole in Johnson Creek. However, no evaluations of these releases were conducted. It is not known how these supplementation efforts have affected the Johnson Creek summer chinook salmon population in terms of stock mixing, population interactions, spawning distribution, or genetic effects. Minimal straying has occurred into Johnson Creek, on the order of one fish with a missing adipose, probably from the MFH SFSR program, per year.

The Nez Perce Tribe implemented the Johnson Creek artificial propagation enhancement (JCAPE) program to supplement summer chinook in Johnson Creek to prevent extirpation of the spawning aggregate, preserve genetic, ecological, and behavioral attributes of these fish, and to build a naturally-self sustaining population. Monitoring and evaluation of this project began in 1998. The Johnson Creek fish in this JCAPE program reared at the McCall Fish Hatchery and released into Johnson Creek at smolt size.

One hundred pairs of chinook salmon of marked (double opercle and adipose fin clipped hatchery fish from MFH were outplanted in Meadow Creek and the East Fork South Fork Salmon River above Meadow Creek. These two locations are approximately ten miles upstream of the mouth of Johnson Creek. Several of these fish were detected in Johnson Creek in 2000. There are strays (identified by the adipose fin clipped) from the MFH in Johnson Creek (Kucera and Blenden 1999, Kucera Nez Perce Tribe unpublished data). 
Table 2. South Fork Salmon River summer chinook salmon releases in Johnson Creek (NPT and PRRG 2001).

\begin{tabular}{cccc}
\hline SFSR Brood Year & Release Date & Fish Released & Fish Size \\
\hline BY 1984 & $8 / 02 / 85$ & 50,000 & Fry \\
BY 1985 & $5 / 09 / 86$ & 177,606 & Fry \\
BY 1986 & $5 / 05 / 87$ & 90,000 & Fry \\
BY 1986 & $6 / 12 / 87$ & 28,400 & Fry \\
BY 1987 & $5 / 09 / 88$ & 194,600 & Fry \\
BY 1987 & $5 / 31 / 88$ & 259,200 & Fry \\
BY 1988 & $8 / 8-10 / 89$ & 290,000 & Fingerling \\
Total Fish Released & $1985-1989$ & $1,290,306$ & Fry/Fingerling \\
\hline
\end{tabular}

\section{McCall Fish Hatchery (South Fork Salmon River)}

McCall Hatchery is located in McCall, Idaho on the North Fork Payette River. McCall Fish Hatchery was constructed in 1980 through the LSRCP program to supplement summer chinook salmon in the SFSR. The South Fork Salmon River is in central Idaho and is a tributary to the main Salmon River. The LSRCP hatchery program provides mitigation for salmon and steelhead losses incurred by the construction and operation of the four lower Snake River hydroelectric dams. The broodstock was initially collected at Little Goose Dam in 1978, at Lower Granite Dam in 1979, and at Lower Granite Dam and the SFSR in 1980 (Howell et al. 1985a, Kucera 1987, IDFG et al. 1990). After 1980, adult returns to the SFSR were used for broodstock purposes. As such, the broodstock is a thought to be a mixture mainly of Snake River summer chinook, but may also contain genetic diversity from spring chinook salmon subpopulations.

\section{$\underline{\text { Big Creek }}$}

Big Creek is a tributary to the Middle Fork Salmon River in the Frank Church Wilderness of No Return in central Idaho. Big Creek chinook salmon are wild fish which have never been supplemented.

\section{$\underline{\text { Capehorn Creek }}$}

Capehorn Creek is a tributary of Marsh Creek at the headwaters of the Middle Fork Salmon River in central Idaho. In 1975, 22,000 spring chinook salmon fry from Rapid River Hatchery 
were outplanted in Capehorn Creek. This was the only nonindigenous fish outplanting in the Middle Fork Salmon River (Matthews and Waples 1991).

\section{Marsh Creek}

Marsh Creek joins Bear Valley Creek to form the Middle Fork Salmon River. Most of this drainage is in the Frank Church River of No Return Wilderness. IDFG operate a weir on Marsh Creek upstream of Capehorn Creek.

\section{$\underline{\text { Pahsimeroi Hatchery Chinook Program (Pahsimeroi River) }}$}

The Pahsimeroi Hatchery is located one mile upstream of the mouth of the Pahsimeroi River in east central Idaho near the town of Ellis. The Idaho Power Company (IPC) as part of the mitigation constructed Pahsimeroi Hatchery in the mid 1960's for chinook salmon and steelhead losses due to the construction and operation of Brownlee Dam, Oxbow Dam, and Hells Canyon Dam on the Snake River (IDFG et al. 1990). Broodstock for the Pahsimeroi Hatchery chinook program was developed from native summer chinook in the Pahsimeroi River in 1968 (Howell et al. 1985a). When the hatchery was expanded in 1980, a spring chinook salmon program was started and the summer chinook program continued. In 1982-1985, over 700 females from the Hayden Creek hatchery in the Lemhi River subbasin were spawned and added to the Pahsimeroi broodstock. In 1987, the hatchery program converted to a summer chinook salmon program and eggs were obtained from the South Fork Salmon River (McCall Hatchery). Transplants from Rapid River spring chinook occurred in 1982, 1987-1989. Skamania hatchery embryos were also transferred to Pahsimeroi Hatchery and the smolts were released into the East Fork Salmon River (Brannon et al. 2000). The genetic diversity contained within the current stock includes at least spring and summer chinook from the Pahsimeroi River, Rapid River (see Rapid River above), Lemhi River and SFSR, and Skamania Hatchery chinook salmon (see MFH above). It is unclear what other program modifications may have occurred. The broodstock makeup has been stable since 1990, meaning only the fish returning to the hatchery have been used for spawning purposes.

The ESA listing of Pahsimeroi chinook salmon varies among brood years (BY). For example: BY 95 are adipose-marked and are all hatchery reserve group non-listed. BY 96, 97, and 98 are all adipose marked listed. BY 99, currently on station, are divided into three groups. The hatchery reserve group are adipose marked non-listed, the hatchery supplementation group are all coded wire tagged and are not adipose marked, the hatchery reserve group are adipose marked only and the high BKD hatchery supplementation group are only CWT. All naturally-produced fish are listed (Garlie personal communication).

\section{$\underline{\text { Pahsimeroi Hatchery Steelhead Program (Pahsimeroi River) }}$}

Idaho's hatchery steelhead program began in 1965 after the Federal Power Commission ordered IPC to transplant Snake River steelhead trapped at Hells Canyon Dam to the Salmon River for mitigation due to the Hells Canyon dam complex construction on the Snake River. This Snake River stock has been the basis for all hatchery A-strain programs in the Salmon River (Ball 1998). B-run steelhead from Dworshak National Fish Hatchery were released in the Pahsimeroi 
River in 1973 - 1974 (Ball 1998, IDFG et al 1990). Skamania (Washington state) Hatchery embryos were also transferred to Pahsimeroi Hatchery and smolts grown in the Pahsimeroi Hatchery were released into the East Fork of the Salmon River (Brannon et al. draft 2001). All wild/ natural (unmarked) steelhead are ESA-listed, but the Pahsimeroi hatchery fish are not ESAlisted. All hatchery fish in Idaho are adipose-clipped (Garlie 2000).

\section{Sawtooth Hatchery (Upper Salmon River)}

The Sawtooth Hatchery is located on the upper Salmon River south of Stanley, Idaho in Sawtooth Mountains. Sawtooth Hatchery was constructed and became operational in 1985 (Hassemer 1998). It is an LSRCP facility designed to compensate spring chinook salmon in the upper Salmon River. These spring chinook must migrate 900 plus miles from the ocean and spawn and rear at an elevation over 6,000 feet. Broodstock development occurred from adult collections on the East Fork Salmon River and the upper Salmon River (Hassemer 1998, IDFG et al. 1990). During the early and late 1970's Rapid River hatchery chinook salmon were released into the East Fork Salmon River and upper Salmon River in response to severe declines in adult escapement (Howell et al. 1985a, Kucera 1987, Hassemer 1998). A total of 985,400 Rapid River hatchery smolts were released in 1978 and 1,012,300 smolts were released in 1979 Howell et al. 1985a). Another report states 914,000 Rapid River smolts were released in 1979 at the present site of Sawtooth Hatchery, and at least 500 returned as adults in 1981 (Yundt personal communication, Waples et al. 1991). Adult broodstock collection has occurred in the upper Salmon River since 1981 (Howell et al. 1985a). The current hatchery broodstock may reflect the genetic diversity contained in both the upper Salmon River chinook and the Rapid River hatchery chinook.

\section{$\underline{\text { Imnaha River }}$}

Historically, "the Imnaha River subbasin of northeast Oregon supported a vital run of steelhead. Correlated with the completion of the dams on the lower Snake River, however, run sizes began to diminish" (Whitesel et al 1998). Neither the number nor the characteristics of natural steelhead in the Imnaha River basin have appeared to respond to the supplementation program (mentioned below) (Whitesel et al 1998).

\section{$\underline{\text { Lookingglass Hatchery (Imnaha River) }}$}

Lookingglass Hatchery is an LSRCP facility in the Grande Ronde subbasin in northeast Oregon near Elgin, constructed in 1982 with adult chinook salmon trapping and smolt acclimation facilities on the Imnaha River, in the Imnaha subbasin. The LSRCP hatchery program provides mitigation for salmon and steelhead losses incurred by the construction and operation of the four

lower Snake River dams. Native Imnaha River chinook salmon was collected in 1982 for the supplementation program (Howell et al. 1985a, Carmichael et al. 1998a) and only this stock has been used.

\section{$\underline{\text { Little Sheep Creek }}$}

Little Sheep Creek is a tributary to the Imnaha River in northeast Oregon. The summer steelhead 
LSRCP supplementation program in the Imnaha River began with the trapping of native steelhead adults in Little Sheep Creek in 1982 (Howell et al. 1985b). In 1983, hatchery-reared smolts were released into Little Sheep Creek and the Imnaha River and adults began to return to the basin in 1985 (Whitesel et al. 1998). The collection, holding and spawning of natural and hatchery adults occurs at a permanent facility on Little Sheep Creek. The embryos are transferred to Wallowa Hatchery for incubation to eyed state. At eye up, the fish are taken to Irrigon Hatchery for rearing to smolts. Then, the smolts are acclimated and released at the Little Sheep Creek facility. Hatchery-produced and naturally produced steelhead from the 1989 and 1990 broods were genetically indistinguishable based on allozyme analyses conducted by Dr. Robin Waples (Whitesel et al. 1998).

\section{Oxbow Fish Hatchery (Snake River)}

The Oxbow Hatchery is located downstream from Oxbow Dam on the Snake River in west central Idaho. The Idaho Power Company (IPC) as part of the mitigation constructed Oxbow Hatchery in the 1962 for chinook salmon and steelhead losses due to the construction and operation of Brownlee Dam, Oxbow Dam, and Hells Canyon Dam on the Snake River. Broodstock for the Oxbow Hatchery steelhead program was developed from native steelhead in the Snake River in 1968 (Hills IDFG personal communication).

\section{Cryopreservation Sample Collections}

Gametes from male chinook salmon were sampled from Lostine River, Catherine Creek, upper Grande Ronde River, Lookingglass Hatchery, Rapid River Hatchery, Lake Creek, the SFSR weir, Johnson Creek, Big Creek, Capehorn Creek, Marsh Creek, Pahsimeroi Hatchery, and Sawtooth Fish Hatchery (Table 3). Sampling at hatchery facilities has been designed to collect gametes from the spectrum of the run. Male steelhead gametes were collected at the Imnaha River, the ODFW weir on Little Sheep Creek, a tributary to the Imnaha River, Dworshak Hatchery, Fish Creek, Pahsimeroi Hatchery, and at Oxbow Hatchery (Table 4). 
Table 3. Snake River basin spring and summer chinook salmon spawning aggregates sampled for semen collection in 2000. Includes total samples cryopreserved, unmarked (wild/natural) and marked (hatchery) fish numbers, dates collected, and the range of percent sperm motility.

\begin{tabular}{|c|c|c|c|c|c|}
\hline Spawning Aggregate & $\begin{array}{l}\text { Total Samples } \\
\text { Cryopreserved }\end{array}$ & $\begin{array}{l}\text { Un- } \\
\text { marked } \\
\text { Fish }\end{array}$ & $\begin{array}{l}\text { Marked } \\
\text { Fish }\end{array}$ & $\begin{array}{l}\text { Collection } \\
\text { Dates }\end{array}$ & $\begin{array}{l}\text { Sperm } \\
\text { Motility } \\
\text { (percent) }\end{array}$ \\
\hline Lostine River & 18 & 18 & 0 & $8 / 23, \& 9 / 7,14$ & $50-90$ \\
\hline $\begin{array}{c}\text { Grande Ronde Captive } \\
\text { Brood }\end{array}$ & 590 & \multicolumn{4}{|c|}{$\begin{array}{c}\text { Lostine River, Catherine Creek and upper Grande } \\
\text { Ronde River captive broodstock samples are reported } \\
\text { as cohort class not by spawning years }\end{array}$} \\
\hline $\begin{array}{c}\text { Imnaha River } \\
\text { Lookingglass Hatchery }\end{array}$ & 71 & 34 & 37 & $8 / 16,23,30 \& 9 / 6,13$ & $20-90$ \\
\hline Rapid River Hatchery* & 51 & 0 & 51 & $8 / 21,24,28$ & $40-90$ \\
\hline $\begin{array}{l}\text { S. Fork Salmon River } \\
\text { McCall Hatchery }\end{array}$ & 55 & 11 & 44 & $8 / 25,29 \& 9 / 8$ & $50-90$ \\
\hline Lake Creek & 15 & 15 & 0 & $8 / 11,14,22$ & $10-90$ \\
\hline Johnson Creek & 34 & 34 & 0 & $8 / 25 \& 9 / 5,6$ & $0-80$ \\
\hline Big Creek & 7 & 7 & 0 & $8 / 15,29$ & $50-90$ \\
\hline Capehorn Creek & 1 & 1 & 0 & $8 / 18$ & 80 \\
\hline Marsh Creek & 7 & 7 & 0 & $8 / 17$ & $20-90$ \\
\hline Pahsimeroi River & 50 & 8 & 42 & $9 / 18,25 \& 10 / 2$ & $20-90$ \\
\hline Upper Salmon River & 40 & 40 & 0 & $8 / 31 \& 9 / 7$ & $10-90$ \\
\hline Totals & 939 & 141 & 798 & $8 / 11-10 / 2$ & $10-90$ \\
\hline
\end{tabular}


Table 4. Snake River basin steelhead spawning aggregates sampled for semen collection in 2000. Includes total samples cryopreserved, unmarked (wild/natural) and marked (hatchery) fish numbers, dates collected, and the range of percent sperm motility.

\begin{tabular}{cccccc}
\hline Spawning Aggregate & $\begin{array}{c}\text { Total Samples } \\
\text { Cryopreserved }\end{array}$ & $\begin{array}{c}\text { Un- } \\
\text { marked } \\
\text { Fish }\end{array}$ & $\begin{array}{c}\text { Marked } \\
\text { Fish }\end{array}$ & $\begin{array}{c}\text { Collection } \\
\text { Dates }\end{array}$ & $\begin{array}{c}\text { Sperm } \\
\text { Motility } \\
\text { (percent) }\end{array}$ \\
\hline Grande Ronde River & 1 & 1 & 0 & $5 / 26$ & 80 \\
Little Sheep Creek & 52 & 11 & 41 & $4 / 11,18,25 \& 5 / 2,9$ & $20-90$ \\
$\quad$ Imnaha River & 2 & 2 & 0 & $5 / 24$ & $?$ \\
$\begin{array}{c}\text { Snake River } \\
\text { Oxbow Hatchery }\end{array}$ & 98 & 3 & 95 & $3 / 24,27 \& 4 / 3,10,17$ & $10-90$ \\
$\begin{array}{c}\text { NFk Clearwater River } \\
\text { Dworshak Hatchery }\end{array}$ & 89 & 0 & 89 & $3 / 14,21,28 \& 4 / 3,11$ & $50-90$ \\
$\quad$ Fish Creek & 1 & 1 & 0 & $6 / 8$ & 40 \\
Pahsimeroi River* & 40 & 0 & 40 & $4 / 20,26$ & $70-90$ \\
Totals & 283 & 18 & 265 & $3 / 14-6 / 8$ & $10-90$ \\
\hline
\end{tabular}

* not ESA listed

Grande Ronde River - chinook salmon captive broodstock

A spring chinook salmon captive broodstock program was initiated in 1995 from the Lostine River, Catherine Creek and upper Grande Ronde River. Excess milt from 590 fish was cryopreserved from the Lostine River (191), Catherine Creek (223) and upper Grande Ronde River (176). One half of the straws from each male is stored at the University of Idaho germplasm repository as a safeguard should anything happen to the storage facility at Bonneville Fish Hatchery.

$\underline{\text { Lostine River }}$ - chinook salmon

The Lostine River flows into the Wallowa River, which empties into the Grande Ronde River. A total of eighteen, unmarked male chinook salmon were sampled in August and September, 2000. Only one of these 18 fish collected in 2000 was collected in the stream. The other 17 gamete samples were spawned at Lookingglass Hatchery from males captured at the adult weir on the Lostine River. There were three jacks; two natural and one hatchery three-year old fish. The one hatchery jack was a fish returning from the conventional supplementation program. This was the seventh consecutive year of cryopreservation sampling in the Lostine River. A total of 33 cryopreserved semen samples taken from 1994 to 2000 are now in storage at the universities. 


\section{Grande Ronde River - steelhead}

One steelhead kelt was sampled at a weir in the upper Grande Ronde River administered by the Confederated Tribes of the Umatilla Indian Reservation. This sample was cryopreserved at our Enterprise Office, and the motility was $80 \%$. This is the first natural steelhead sampled from this river system.

\section{Dworshak National Fish Hatchery (North Fork Clearwater River) - steelhead}

Semen was cryopreserved from 89 hatchery steelhead that were held for spawning at the Dworshak National Fish Hatchery in Ahsahka, Idaho on the Clearwater River. All of these fish were hatchery origin steelhead, and are ESA-listed fish. These samples were collected in coordination with the U.S. Fish and Wildlife Service during hatchery spawning operations. This was the second year of steelhead cryopreservation sampling by the Tribe at this hatchery. There are a total of 151 Dworshak Hatchery steelhead samples in storage.

\section{Selway River}

U.S. Geological Society (formerly National Biological Survey or NBS) transferred a small inventory of cryopreserved milt from Selway River steelhead to the germplasm repository. These samples were collected in 1994 as part of a stock/productivity study. Adult steelhead were collected from the fish ladder that bypasses Selway Falls. Genetic analysis was conducted on each fish to determine homozygosity at a specific allele. Excess milt from the homozygous males on the last spawning day (April 25, 1994) were cryopreserved. Five Selway River steelhead samples in $5.0 \mathrm{~mL}$ straws are now part of the salmonid germplasm repository in the WSU tanks at Pullman, Washington.

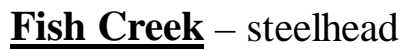

The U.S. Geological Society (formerly National Biological Survey or NBS) collected and cryopreserved milt from Fish Creek steelhead in 1993 as part of a stock/productivity study. Ten male sperm samples frozen in $5.0 \mathrm{~mL}$ straws were transferred to the salmonid germplasm repository in the WSU tanks in Pullman, Washington. One downstream migrating, natural steelhead kelt was captured at the Idaho Department of Fish and Game (IDFG) weir and artificially spawned to collect sperm on June 8, 2000.

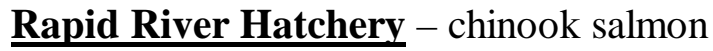

Rapid River Hatchery, administered by the IDFG, chinook salmon semen was collected starting in 1998. In 2000, chinook milt (51 samples) considered excess to the production needs was cryopreserved. These fish are not ESA-listed. Two hundred seventeen samples are in storage from 1998-2000.

South Fork Salmon River Weir - chinook salmon

Fifty-five fish were sampled over a period of two weeks at the South Fork Salmon River McCall 
Hatchery weir with Idaho Department Fish and Game hatchery personnel. The breakdown of the origin of these fish is as follows: 43 were adipose fin-clipped (hatchery origin), and 11 were natural fish. One of the adipose-clipped fish was netted and sampled in Johnson Creek from outplanted fish. This was the fifth year of cryopreservation sampling at the South Fork Salmon River weir. A total of 256 cryopreserved semen samples taken from 1996 to 2000 are now in storage.

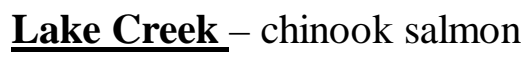

Fifteen wild adult male fish were sampled in Lake Creek on August 11, 14 and 22. Five female chinook salmon were netted and immediately released upon identification. This was the fifth year of cryopreservation sampling in Lake Creek, a tributary of the Secesh River in the South Fork Salmon River watershed. A total of 31 cryopreserved semen samples taken in 1996 through 2000 are now in storage.

Johnson Creek - chinook salmon

A total of 34 wild/natural chinook salmon were cryopreserved from Johnson Creek in 2000. A high proportion (44\%) of jacks (15 out of 34) were sampled in 2000 (Figure 8). One adiposeclipped salmon was sampled in Johnson Creek. Adipose fin-clipped fish are hatchery fish, presumably from the McCall Hatchery. This fish is included in the South Fork Salmon River counts. Seven fish were netted in Johnson Creek and spawned artificially. The Nez Perce Tribe initiated a supplementation program in 1998 on this stream, and the adult weir was in place in 2000. The remaining 27 chinook were collected at the weir on Johnson Creek and spawned for cryopreservation purposes after broodstock fertilization occurred. Johnson Creek is a tributary of the East Fork South Fork Salmon River. This was the fourth year of chinook cryopreservation sampling in Johnson Creek, for a total of 63 semen samples cryopreserved. 


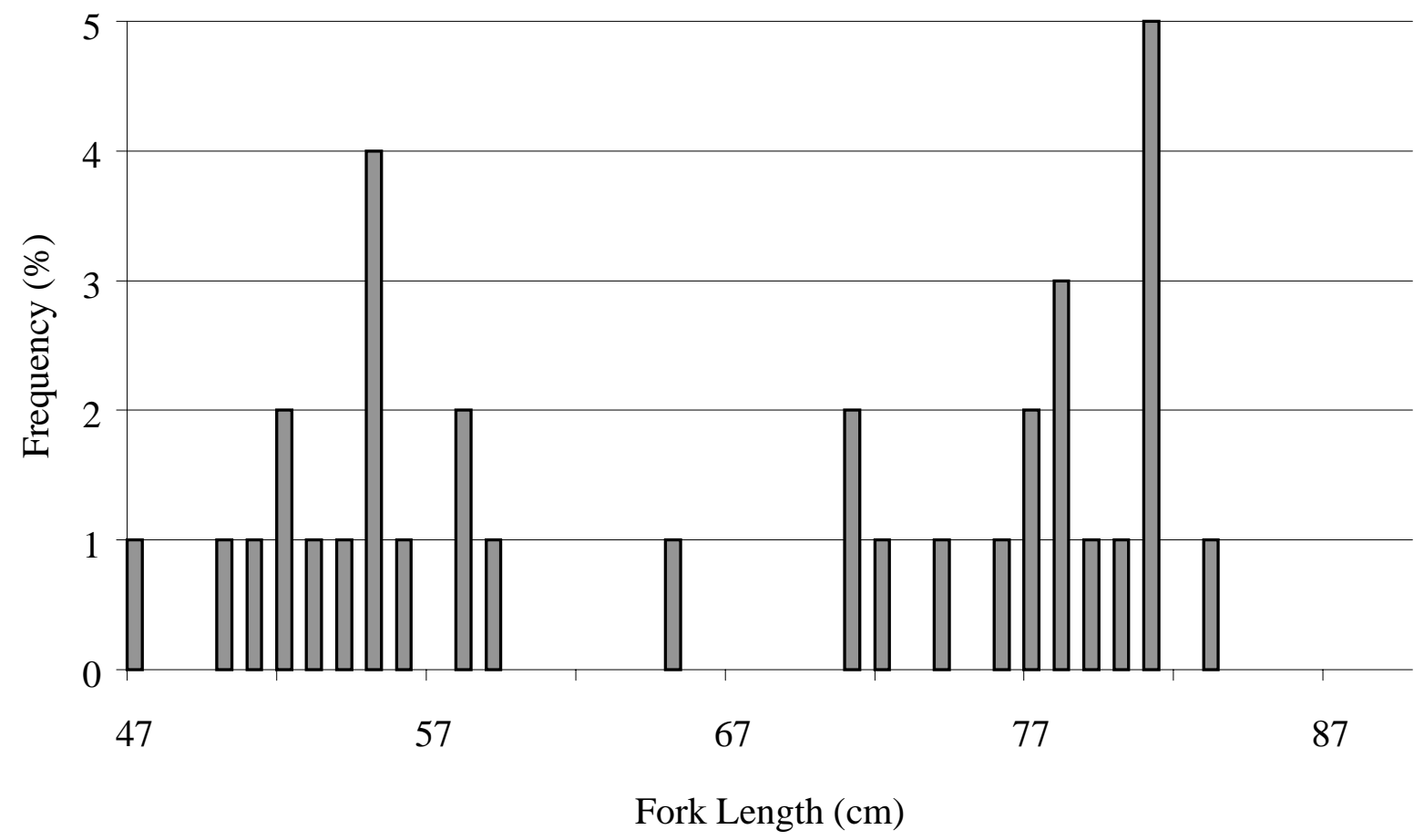

Figure 6. Length frequency distribution of male chinook salmon sampled for cryopreservation in Johnson Creek in 2000.

$\underline{\text { Big Creek }}$ - chinook salmon

We attempted to collect semen from chinook salmon in Big Creek, a tributary to the Middle Fork Salmon River, for nine years. Big Creek experienced three consecutive years (1994-1996) of cohort collapse when samples were not obtained. No salmon were netted in 1999 in the stream either. On August 15 and 29, 2000, six male chinook were sampled for cryopreservation purposes. One male was sampled on two different days. One female (netted and immediately released). A total of 31 cryopreserved semen samples taken in 1992, 1993, 1997, 1998 and 2000 are now in storage.

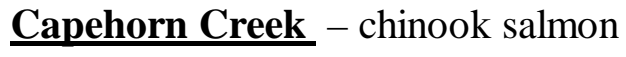

One male salmon was sampled at Capehorn Creek in 2000. Only eight redds were observed in Capehorn Creek in 2000, which limited the potential for adult male collection. Nine samples are in storage from this headwater stream in the Middle Fork Salmon River drainage.

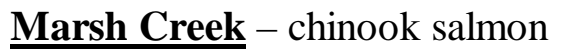

Seven semen samples from Marsh Creek were collected in 2000. There are 13 samples from 1997, 1998 and 2000 cryopreserved in the gene bank. 
Pahsimeroi Hatchery (Pahsimeroi River) - chinook salmon and steelhead

Pahsimeroi Hatchery summer chinook salmon and A-run steelhead semen was collected at the hatchery starting in 1999. This year chinook milt from 50 fish (42 marked and 8 unmarked samples) considered excess to the production needs were sampled and frozen (Figure 9). Steelhead sperm from 40 fish were frozen. A total of 81 chinook and 87 steelhead gametes are cryopreserved in liquid nitrogen now.

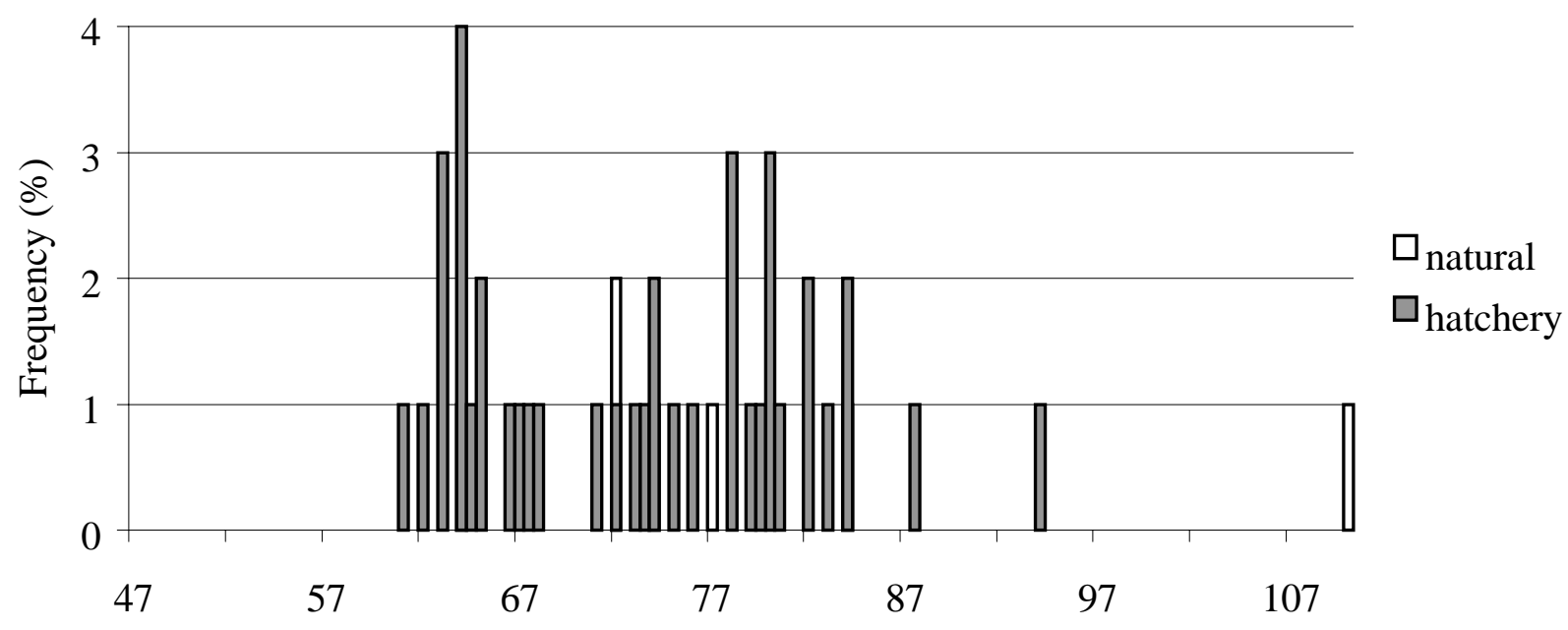

Fork Length $(\mathrm{cm})$

Figure 7. Length frequency distribution of hatchery and natural male chinook salmon sampled for cryopreservation at the Pahsimeroi Hatchery in 2000.

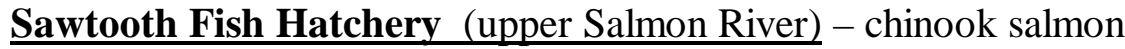

Forty fish spawned at the Sawtooth Fish Hatchery from the upper Salmon River were sampled in 2000. All of the chinook salmon sampled in 2000 were wild/natural fish. A total of 172 samples from the Sawtooth Hatchery have been cryopreserved.

$\underline{\text { Imnaha River }}$ - steelhead

Two steelhead kelts were sampled at a smolt emigrant trap in the lower Imnaha River (river kilometer 7). These wild/natural fish were heading downstream after assumed natural spawning had occurred. The two milt samples were pooled at the universities because the volume was so low. It is not normal procedures to pool samples from different fish, but neither sample was large enough to cryopreserve alone.

Little Sheep Creek - steelhead

Steelhead semen was collected from 52 fish at the adult weir on Little Sheep Creek that is operated by the Oregon Department of Fish and Wildlife (Figure 6). Forty-one of these fish had 
an adipose or an adipose plus left ventral fin clip, and gametes were collected from 11 unmarked fish. Little Sheep steelhead have been sampled since 1997 and a total of 107 cryopreserved samples are in the germplasm repository.

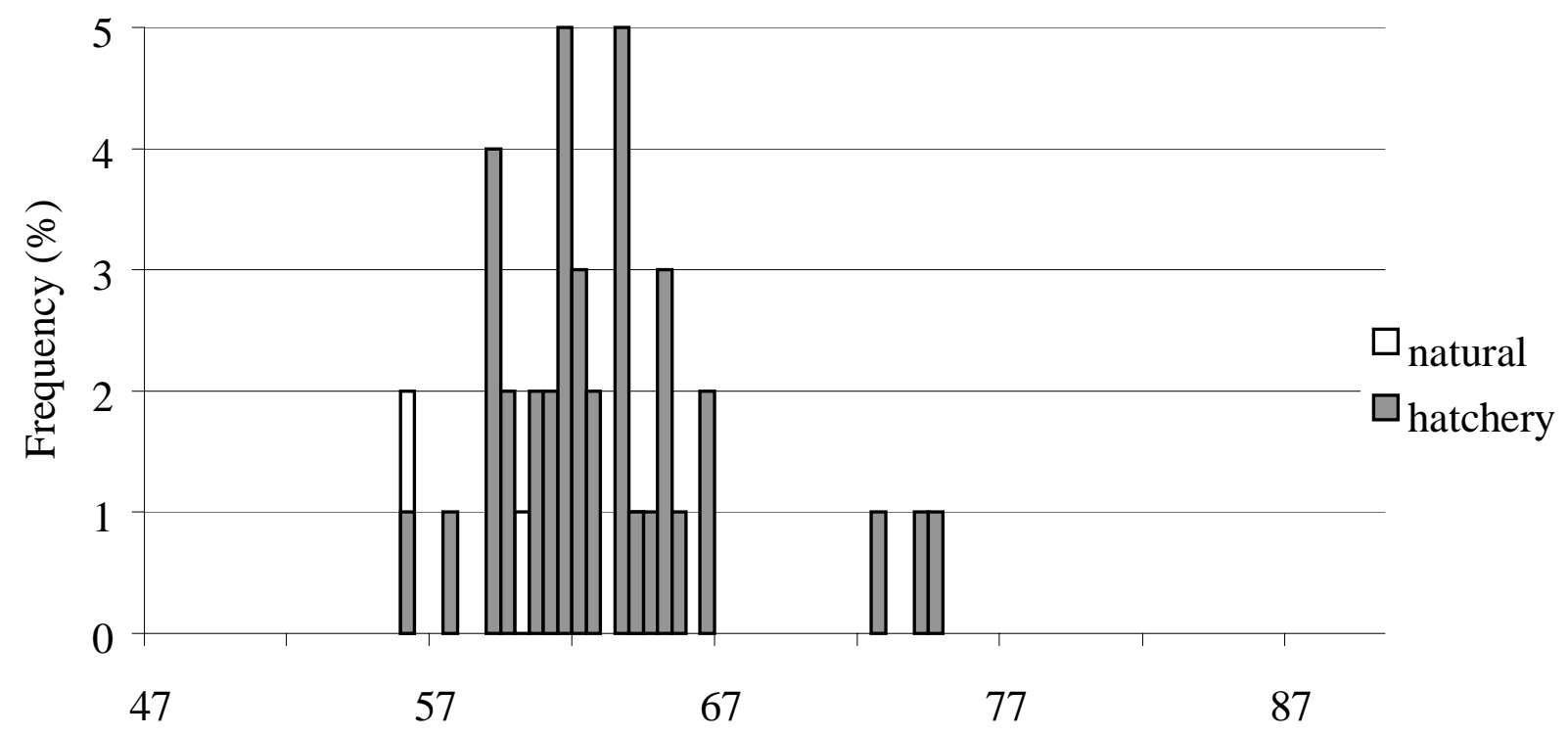

Fork Length $(\mathrm{cm})$

Figure 8. Length frequency distribution of hatchery and natural male steelhead sampled for cryopreservation in Little Sheep Creek in 2000.

Lookingglass Fish Hatchery (Imnaha River) - chinook salmon

Sperm was cryopreserved from 71 Imnaha River chinook from the Oregon Department of Fish and Wildlife (ODFW) Lookingglass Fish Hatchery. Semen from 34 natural and 37 hatchery fish was frozen. All of these fish were either adipose fin-clipped (37) or not fin- clipped (34 naturals), all are ESA listed fish. These samples were collected in coordination with the ODFW during hatchery spawning operations. A total of 383 cryopreserved semen samples taken from 1994 - 2000 are now in storage. A substantial (18 of the 71 chinook or $25 \%$ of the fish sampled for cryopreservation were jacks $(<600 \mathrm{~mm})$ (Figure 7$)$. 


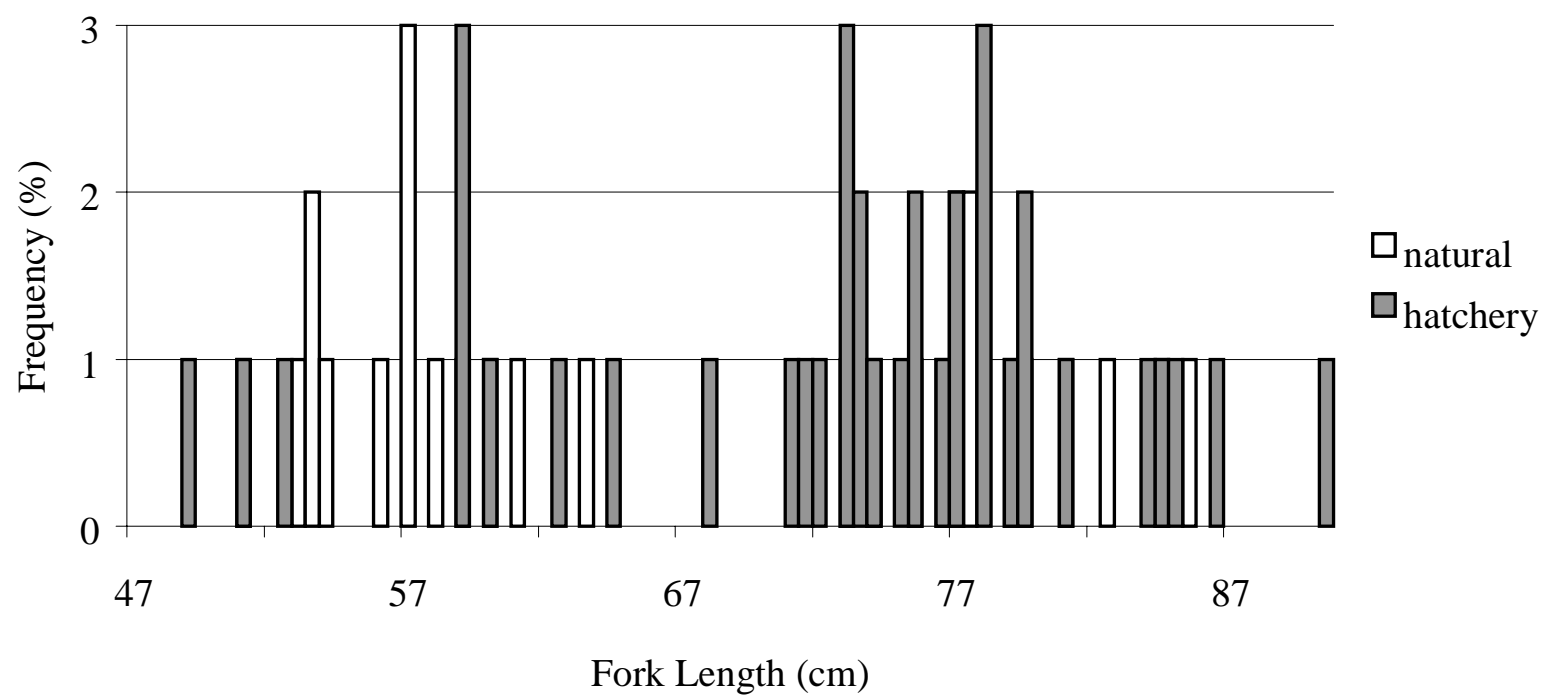

Figure 9. Length frequency distribution of hatchery and natural male chinook salmon sampled for cryopreservation in the Imnaha River in 2000.

Oxbow Hatchery (Snake River) - steelhead

Snake River steelhead milt was sampled at Oxbow Hatchery for the first time in 1999. In 2000, hatchery steelhead milt ( 98 samples) considered excess to the production needs was collected and cryopreserved over the spectrum of the spawning season from early March through April. These fish are trapped below Hells Canyon dam in the fall and again starting in February. Three unmarked, possibly wild steelhead were cryopreserved.

Fertility Trials

Fertilization experiments were conducted again at both universities in 2000 using ESA non-listed chinook salmon gametes. WSU acquired the eggs from three female chinook salmon at Lyons Ferry Hatchery on September 13. The milt from 5 males in the germplasm repository frozen in August 2000 fertilized those eggs at $1 \mathrm{pm}$ on the same day. The eggs were pooled and three batches of eggs were fertilized with a single straw each. Three straws were used from each of the five males tested (Appendix 1, Table 4). University of Idaho obtained gametes from Dworshak National Fish Hatchery ESA non-listed chinook salmon.

Average fertilization rate for the WSU experiment was $60 \%$ with a range from 15.9 to $74.1 \%$. Average fertilization rate for the UI experiment was 59.9\% with a range from 26.6 to $76.6 \%$. Approximately $60 \%$ fertilization using cryopreserved semen is what can be expected if 2000 frozen chinook salmon sperm is used for production. Lower fertilization rates using cryopreserved sperm may be acceptable where genetic concerns warrant them.

Salmonid Genetic Analysis

The University of Idaho Center for Salmonid and Freshwater Species at Risk analyzed, but has 
not reported on the results of the chinook salmon collected in 1999. These results are being refined further, since new markers and analyses are continually being developed.

Washington State University analyzed and reported results of preliminary genetic analysis of selected steelhead cryopreserved in 2000. Small sample size and availability of funds preclude a more complete analysis. The mitochondrial DNA haplotypes (Appendix 3) and microsatellite allelic distribution appear to agree on the similarities and relationships among Snake River basin steelhead trout collected by the Tribe. Furthermore, both reflect differences in haplotype and allele frequencies between 1999 and 2000, indicating that there are differences in the genetic diversity of these populations between the two years. With these differences, it is difficult to make conclusions about the overall relationships among some stocks.

It is also important to remember that both of the above genetic analyses were conducted on putatively neutral markers that are not subject to natural selection, as compared to adaptive markers. It is difficult to analyze adaptive markers, so this is rarely done. Some adaptive traits are: distance migrated, size, run timing, smolt emergence, and habitat characteristics (such as water temperature, velocity, water quality) chosen by the fish.

\section{DISCUSSION}

Semen samples from 632 wild/natural and hatchery steelhead and spring and summer chinook salmon were collected for cryopreservation in 2000. Also, 590 samples from the Grande Ronde chinook salmon captive broodstock were added to the germplasm repository. A total of 1,220 samples from chinook salmon are stored in the repository. Chinook salmon spawning aggregates to sample were chosen based upon geographic distribution. More semen samples for cryopreservation were collected this year than any other year.

A total of 347 spring and summer chinook were sampled with 172 of those fish, or $50 \%$, being of natural origin. Adult chinook salmon migrating upstream past Bonneville Dam from March through May, and June through July are categorized as spring- and summer-run fish respectively (Burner 1951). Some streams in the Snake River are considered to have only spring chinook, some mainly summer-run fish (e.g., those in the SFSR), and some both forms (e.g., Middle Fork Salmon River and upper Salmon River). In most cases where the two forms coexist, spring-run fish spawn earlier and in the headwaters of the tributaries, whereas summer chinook spawn later and farther downstream (Matthews and Waples 1991). We are sampling chinook in the major river subbasins in the Snake River drainage, thereby preserving gametes from both runs.

A total of 283 steelhead male gametes were cryopreserved (265 were hatchery fish, 18 were unmarked wild/natural fish). Both of the major extant groups (A and B-run) of steelhead in the Snake River basin were sampled. It has been challenging to sample natural steelhead. There are few collection facilities, high water, inclement weather for flying samples, difficulties in identifying spawning aggregates combine to hinder stream collections. Thus, mainly Snake River hatchery A-run and Dworshak hatchery b-run fish have been preserved. The A-group passes Bonneville Dam (Columbia River kilometer 235) before August 25 and the B-group pass Bonneville after August 25 (CBFWA 1990, IDFG 1994), but both reach the lower Snake River dams at about the same time. A-run steelhead are defined as predominately one ocean fish, while 
B-run steelhead are defined as two ocean (IDFG 1994). A-run steelhead are believed to occur throughout the steelhead-bearing streams of the Snake River basin (Busby et al. 1996). B-run steelhead are thought to be produced only in the Clearwater River, Middle Fork Salmon River and South Fork Salmon River (IDFG 1994). Steelhead of the B-group are larger, averaging 1115 pounds (or 5-7 kilograms) with maximum size up to 35 pounds (or 16 kilograms).

Sampling of wild/natural steelhead is restricted to downstream migrating kelts. A new, interesting opportunity for sampling steelhead gametes was explored in 2000, which is collecting and stripping kelts (spawned-out fish) as they are handled at the separator for downstream passage at the Lower Granite Dam. We coordinated with an ongoing kelt reconditioning project at Lower Granite Dam. Three days were spent at the separator at Lower Granite Dam, but all male steelhead kelts produced no milt when artificially spawned.

Sustained productivity of salmonids in the Pacific Northwest is possible only if the genetic resources that are the basis of such productivity are maintained (National Research Council 1996). Much of the genetic diversity that historically existed probably has already been lost. The germplasm repository is an effort to conserve the genetic diversity that remains in existing salmon runs and steelhead runs for future management options. The spawning aggregates sampled represent only a small portion of the stocks in the Snake River basin. We have attempted to sample and preserve salmonid genetic diversity within the major river subbasins in the Snake River basin. An adequate number of individuals should be sampled from each genetically unique conservation unit to ensure conserving the genetic diversity contained in the runs of chinook salmon and steelhead.

Sampling of male chinook salmon in the streams is restricted to the later part of the spawning period to avoid affecting reproductive success. By limiting the sampling period, the genetic diversity contained in early spawning fish may not be preserved in the germplasm repository. Because salmonids produce excess germplasm and regenerate milt readily, it makes sense to sample male steelhead and chinook salmon as they migrate upstream towards their spawning sites before they spawn.

The urgency to create a germplasm repository becomes apparent when reviewing the status of the runs (Kucera 1998) and the number of samples being preserved. The number of samples collected in the streams in 2000 was minimal. Few fish were found in some streams; 49 for chinook and 4 for steelhead.

The use of cryopreserved sperm to fertilize eggs in a hatchery setting enables hatchery managers to produce threatened salmonids via captive broodstock programs or to enhance genetic diversity in conventional hatchery programs. Captive breeding programs require consideration of small population vulnerabilities to preserve high levels of genetic diversity (Ryder et al. 2000). It is estimated that 200 unrelated individual samples are needed to establish a breeding program (Cloud - personal communication).

The "ownership" of the genetic resources and responsibility for the timing and circumstances of attempts at restoration are complicated issues to be resolved. Many of the controversial practical and ethical issues related to captive breeding populations and their reintroduction into restored 
and changing natural habitats apply to restoration via genome banking (Corley-Smith and Brandhorst 1999). In the future, we believe that more requests will be made to use cryopreserved semen in hatchery production programs and in research. We recommend and support only the ethical use of cryopreserved genetic material from the germplasm repository. The judicious use of this vital genetic resource is imperative. To that end, we will provide criteria for accessing and using cryopreserved semen samples from the germplasm repository that will assist in rational use and inventory management. A form has been developed to request cryopreserved semen from the germplasm repository and is available for use (Appendix 2). The semen request form's main function is for inventory management of the $0.5 \mathrm{~mL}$ straws and $5.0 \mathrm{~mL}$ straws. Semen requests are further reviewed by the Snake River Germplasm Repository Committee to further ensure rational use. A database of the germplasm inventory has been established and is available for use.

\section{Other Gene Banking Efforts in the Snake River Basin}

Idaho Department of Fish and Game have been cryopreserving Redfish Lake sockeye salmon as part of the captive sockeye program. They also freeze male gametes from chinook salmon from the Lemhi River, Yankee Fork and the East Fork Salmon River from the captive rearing project. IDFG were involved in cryopreserving the same chinook salmon gametes as the NPT at Sawtooth and Pahsimeroi hatcheries in 1999. The Tribe's captive broodstock evaluation project cryopreserves male gametes from the captive Lostine River, Grande Ronde and Catherine Creek chinook salmon broodstocks at Bonneville Hatchery. Washington Department of Fish and Wildlife freezes Snake River fall chinook and spring chinook from the Tucannon River.

\section{RECOMMENDATIONS}

The genetic diversity within existing chinook salmon and steelhead spawning aggregates is not replaceable and should be conserved to protect present and future options (National Research Council 1996). The recommendation of the gamete preservation project is to cryopreserve gametes from as many genetically diverse conservation units as possible. Coordination with other Tribal, state and federal agencies will continue to help identify unique spawning aggregates. Further genetic analysis may help determine population structure of chinook salmon (Brannon et al. draft 2000) and steelhead subpopulations.

Snake River chinook salmon and steelhead are in a downward spiral toward extinction. This is the case with the wild and hatchery fish. The gene bank has an inventory of both wild and hatchery salmonids, though many more hatchery fish, due to the ease of collections at a known time and location. Future collections should emphasize semen collection from wild/natural fish. The cryopreservation project would benefit from input from Tribal, state, and federal agencies to identify steelhead conservation units for gamete cryopreservation.

It would be more efficient to freeze the few wild fish gametes collected at streamside. This option of cryopreserving the gametes on dry ice, then nitrogen, will be explored in 2000 . We will store the samples in a 32-liter dewar, then transfer the straws to the main repository at the end of the spawning period for that species.

Fertility trials are conducted after each species' spawning season as a standard practice. The 
trials involve fertilizing eggs with cryopreserved versus fresh sperm. Our field versus laboratory techniques will be evaluated in the same manner.

The goal of the gene bank is to preserve genetic diversity. Diversity can be quantified with analysis of the DNA from sampled fish. We recommend that the genetic analysis and report of results keep current with the cryopreservation of the gametes to make project evaluation possible. The means to preserving species genetic diversity is collection of at least 100 samples per year from each spawning aggregate, covering at least five collection years for chinook and at least four years for steelhead.

It is expected with the ESA listing of bull trout as a threatened species, that more requests for cryopreserving male gametes from this species will occur. It is wise to move proactively to cryopreserve genetic diversity while the spawning aggregates of these species are relatively healthy instead of reacting to threatened population levels. We recommend cryopreserving male gametes from bull trout in 2000 .

Currently a limited and relatively uncoordinated effort exists to preserve tissues, gametes and frozen viable cells (Ryder et al. 2000). We are being insightful in proposing a regional aquatic germplasm repository based in Moscow, Idaho. Sagacious managers of gene banks should coordinate at a national and worldwide level.

\section{SUMMARY}

The cryopreservation project currently has a total of 1,880 chinook salmon and 540 steelhead semen samples in the germplasm repositories at the University of Idaho and Washington State University. We collected 1,290 of the chinook gametes and we are storing 590 samples for the Grande Ronde chinook salmon captive broodstock program. Each university has backup freezer tanks, which act as a safeguard mechanism in case of primary tank failure. They also serve as long-term archival storage, which is not disturbed.

Semen collection should continue until sufficient genetic diversity from as many salmonid subpopulations as possible is represented in the germplasm repository. Fish in some streams such as Big Creek are low in abundance and may require a longer sampling period. Genetic analysis needs to continue annually as semen samples are collected for cryopreservation. Assessment of genetic resources can serve a valuable planning purpose in the overall conservation effort, as well as in determination and management of the well being of species and the richness of ecosystems (Ryder et al. 2000). 


\section{ACKNOWLEDGMENTS}

The Nez Perce Tribe would like to thank: Joe Cloud and his staff at the University of Idaho, Gary Thorgaard and Paul Wheeler and staff at Washington State University for cryopreservation assistance, the storage facilities, and recommendations to make this a better program. Also thank you to: Kim Brown, Krista Nichols, and Gary Thorgaard of WSU for the steelhead genetic analysis, and Matt Powell, and Jeff Stephenson at the UI Fish Genetics Lab for the chinook salmon genetic analysis. The U.S. Fish and Wildlife Service Lower Snake River Compensation Plan program provided cost-share funds for cryopreservation activities.

We also thank the hard work and cooperation of our field crews: Mary Edwards, John Gebhards, Vonda Kirk, Joe McCormack, Aaron Penney, Dave Faurot, Rich Miller, Kelly Gillogly, Ryan Jain, Mitch Daniel, Mike Blenden, Sarah Aavedel, Michelle Wilson, Peter Cleary and the Smolt Monitoring Project crews, Jay Hesse, Doug Nelson, Mitch Daniel, Jason Vogel, and Jim Harbeck.

We greatly appreciate the cooperation and assistance of: Gene McPherson at the Idaho Department Fish and Game McCall Fish Hatchery, Greg Davis at Oregon Department of Fish and Wildlife Wallowa Hatchery, Bob Lund at the Oregon Department of Fish and Wildlife Lookingglass Hatchery, Rick Lowell at Rapid River Hatchery, Todd Garlie at Pahsimeroi Hatchery, Kent Hill at Oxbow Hatchery, Bob Semple at Dworshak National Fish Hatchery, Idaho Power for the use of its Oxbow airstrip, and Brent Snider at the Sawtooth Fish Hatchery, Alan Byrne and crews at the Fish Creek weir. Also, thanks to Interstate Aviation for flying our chinook and steelhead gametes.

The Nez Perce Tribe is appreciated for its administration of this project. 


\section{LITERATURE CITED}

Ali, J. and J. N. Shelton. 1993. Successful vitrification of day-6 sheep embryos. Journal of Reproduction and Fertility. 99:65-70.

Armstrong, R. and P. A. Kucera. 1999. Salmonid Gamete Preservation in the Snake River Basin. 1998 Annual Report. Prepared for Bonneville Power Administration. Nez Perce Tribe Department of Fisheries Resources Management. Lapwai, Idaho.

Armstrong, R. D. and P. A. Kucera. 2000. Salmonid Gamete Preservation in the Snake River Basin. 1999 Annual Report. Prepared for Bonneville Power Administration. Nez Perce Tribe Department of Fisheries Resources Management. Lapwai, Idaho.

Ashwood-Smith, M. J. 1980. Low temperature preservation of cells, tissues and organs. Pages 19-44 in M. J. Ashwood-Smith and J. Farrant, editors. Low Temperature Preservation in Medicine and Biology. Pitman Medical Ltd., Tunbridge Wells, Kent, UK.

Ball, K. 1998. Summer steelhead program in the Salmon River Basin, Idaho. Pages 59-69 in Proceedings of the Lower Snake River Compensation Plan Status Review Symposium, February 3-5, 1998. Idaho Department of Fish and Game. Salmon, Idaho.

Brannon, E., D. Campton, M. Powell, T. Quinn, and A. Talbot. Draft 2000. Population structure of Columbia River chinook salmon and steelhead trout and application to existing populations. Completion Report, Bonneville Power Administration, Portland, Oregon.

Burge, H.L., M. Faler, R.B. Roseberg, and R.N. Jones. 2000. Adult steelhead returns to Dworshak NFH in 1999-00 and prognosis for 2000-01. Appendix B. U.S. Fish and Wildlife Service. Ahsahka, Idaho.

Burner, C.J. 1951. Characterisitics of spawning nests of Columbia River salmon. Fish. Bull. $1: 1-50$.

Busby, P.J., T.C. Wainwright, G.J. Bryant, L.J. Lierheimer, R.S. Waples, F.W. Waknitz, and I.V. Lagomarsino. 1996. Status of West Coast Steelhead from Washington, Idaho, Oregon, and California. NOAA Technical Memo. NMFS-NWFSA-27. Department of Commerce National Marine Fisheries Service. Seattle, Washington.

Carmichael, R.W., S.J. Parker, and T.A. Whitesel. 1998a. Status review of the chinook salmon hatchery program in the Imnaha River basin, Oregon. Pages 119-140 in Proceedings of the Lower Snake River Compensation Plan Status Review Symposium, February 3-5, 1998. Oregon Department of Fish and Wildlife, La Grande, Oregon. 
Carmichael, R.W., S.J. Parker, and T.A. Whitesel. 1998b. Status review of the spring chinook salmon hatchery program in the Grande Ronde River basin, Oregon. Pages 82-97 in Proceedings of the Lower Snake River Compensation Plan Status Review Symposium, February 3-5, 1998. Oregon Department of Fish and Wildlife, La Grande, Oregon.

Cloud, J. G., and C. Osborne. 1997. Cryopreservation of Salmonid Sperm. University of Idaho, Moscow, Idaho.

Columbia Basin Fish and Wildlife Authority (CBFWA). 1990. Integrated system plan for salmon and steelhead production in the Columbia River Basin. Columbia Basin System Planning, 449 p. and 40 subbasin volumes. (Available from Northwest Power Planning Council, 851 S.W. Sixth, Suite 1100, Portland, OR 97204-1348.)

Corley-Smith, G.E. and B.P. Brandhorst. 1999. Preservation of endangered species and populations: A role of genome banking, somatic cell cloning, and androgenesis? Molecular Reproduction and Development. 53:363-367.

Crateau, E. 1995. Straying of hatchery origin spring/summer-run chinook salmon in the Grande Ronde basin. In W. Stewart Grant (editor). 1997. Genetic effects of straying of nonnative fish hatchery fish into natural populations: proceedings of the workshop. U.S. Dep. Commerce, NOAA Technical Memorandum NMFS-NWFSC-30, 130p

Dobrinsky, J.R., F.F. Hess, R.T. Duby, J. M Robl. 1991. Cryopreservation of Bovine Embryos by vitrification. Theriogenology. Vol. 35 No.1.

Fahning, M.L. and M.A. Garcia. 1992. Status of cryopreservation of embryos from domestic animals. Cryobiology 29:1-18.

Faurot, D., R. Armstrong, P. A. Kucera, and M. L. Blenden. 1998. Cryopreservation of adult male spring and summer chinook salmon gametes in the Snake River Basin. 1997 Annual Report. Prepared for Bonneville Power Administration. Nez Perce Tribe Department of Fisheries Resources Management. Lapwai, Idaho.

Garlie, T. 2000. Pahsimeroi Hatchery Manager. Idaho Department of Fish and Game. Personal communications.

Hassemer, P.F. 1998. Upper South Fork Salmon River Summer Chinook Salmon. Pages 167176 in Proceedings of the Lower Snake River Compensation Plan Status Review Symposium, February 3-5, 1998. Idaho Department of Fish and Game, Nampa, Idaho.

Hayashi, S., K. Kobayashi, J. Mizuno, K. Saitoh, S. Hirano. 1989. Birth of piglets from frozen embryos. The Veterinary Record. July 8, 1989. 
Howell, P., D. Jones, D. Sarnecchia, L. LaVoy, W. Kendra, and D. Ortmann. 1985(a). Stock assessment of Columbia River anadromous salmonids. Volume I: Chinook, coho, chum and sockeye salmon stock summaries. Final Report, Bonneville Power Administration, Project No. 83-335. Portland, Oregon.

Howell, P., D. Jones, D. Sarnecchia, L. LaVoy, W. Kendra, and D. Ortmann. 1985(b). Stock assessment of Columbia River anadromous salmonids. Volume II: Steelhead stock summary. Final Report, Bonneville Power Administration, Project No. 83-335. Portland, Oregon.

Idaho Department of Fish and Game, Nez Perce Tribe, and Shoshone-Bannock Tribes. 1990. Salmon River subbasin salmon and steelhead production plan. Prepared for: Northwest Power Planning Council, Portland, Oregon.

Idaho Department of Fish and Game (IDFG). 1994. Documents submitted to the ESA Administrative Record for west coast steelhead by Eric Leitzinger, 18 October 1994. (Available from Environmental and Technical Services Division, National Marine Fisheries Service, 525 N.E. Oregon Street, Suite 500, Portland, OR 97232.)

Kiefer, S. M. Rowe, and K. Hatch. 1996. Stock summary reports for Columbia River anadromous salmonids. Volume V: Idaho subbasins. Prepared for Bonneville Power Administration. Portland, Oregon.

Kono, T., O. Suzuki, and Y. Tsunoda. 1988. Cryopreservation of rat blastocysts by vitrification. Cryobiology. 25: 170-173

Kucera, P.A. 1987. Nez Perce Tribal review of the Salmon River Lower Snake River Compensation Plan. Working Paper. Technical Report FRI/LSR-87-18. Prepared for the U.S. fish and Wildife Service LSRCP Program. Nez Perce Tribe Department of Fisheries Management. Lapwai, Idaho.

Kucera, P. A. 1998. Nez Perce Tribe vision of the future for chinook salmon management in the South Fork Salmon River. Pages 177-185 in Proceedings of the Lower Snake River Compensation Plan Status Review Symposium, February 3-5, 1998. Nez Perce Department of Fisheries Resources Management, Lapwai, Idaho.

P.A. Kucera and M.L. Blenden editors. 1999. Lower Snake River Compensation Plan Hatchery Evaluation Studies Annual Project Report. Nez Perce Tribe Department of Fisheries Resources Management. Lapwai, Idaho.

Matthews, G.M., and R.S. Waples. 1991. Status review for Snake River Spring and Summer Chinook Salmon. National Marine Fisheries Service, Seattle, Washington. 
Milner 1997. In Howell, P., D. Jones, D. Sarnecchia, L. LaVoy, W. Kendra, and D. Ortmann. 1985(b) Stock assessment of Columbia River anadromous salmonids. Volume II:

Steelhead stock summaries. Final Report, Bonneville Power Administration, Project No. 83-335. Portland, Oregon.

Mounib, M. S. 1978. Cryogenic preservation of fish and mammalian spermatozoa. Journal of Reproductive Fertility 53:13-18.

National Research Council. 1996. Pages 145-163 in Upstream: salmon and society in the Pacific Northwest. National Academy Press, Washington, DC.

Nez Perce Tribe and Columbia River Inter-Tribal Fish Commission Production and Restoration Research Group. 2001. Johnson Creek Artificial Propagation Enhancement Project Hatchery and Genetic Management Plan. Nez Perce Tribe Department of Fisheries Resources Management, McCall, Idaho.

Oregon Fish Commission. 1905. Annual Reports of the Department of Fisheries of the Sate of Oregon for the years 1903 and 1904 to the Twenty-Third Legislative Assembly. Salem, Oregon.

Oregon Fish Commission. 1906. Annual Reports of the Department of Fisheries of the Sate of Oregon to the Legislative Assembly, Twenty-Fourth Regular Session 1907. Salem, Oregon.

Rall, W.F. and G.M. Fahy. 1985. Ice-free cryopreservation of mouse embryos at $-196^{\circ} \mathrm{C}$ by vitrification. Nature. Vol. 313. P.573-575.

Rhine, D. 1998. Summer steelhead Program, Clearwater Fish Hatchery, Clearwater River Basin, Idaho. Pages 53-58 in Proceedings of the Lower Snake River Compensation Plan Status Review Symposium, February 3-5, 1998. Idaho Department of Fish and Game, Lewiston, Idaho.

Ryder, O.A., A. McLaren, S. Brenner, Y.Zhang, K. Benirschka. 2000. DNA Banks for Endangered Animal Species. Science. Volume 288. Page 275.

Stoss, J. 1983. Fish gamete preservation and spermatozoan physiology. Pages 305-350 in W. S. Hoar, D. J. Randell, and E. M. Donaldson editors. Fish Physiology. Vol. 9, part B, Academic Press, New York.

Summerfelt, R.C. and L.S. Smith. 1990. Anesthesia, Surgery, and Related Techniques. Page 213. in C.B. Schreck and P. B. Moyle editors. Methods for Fish Biology. American Fisheries Society, Bethesda, Maryland.

Trounson, A. and L .Mohr. 1983. Human pregnancy following cryopreservation, thawing and transfer of an eight-cell embryo. Nature. Vol. 305. P. 707-709. 
Waples, R. S., D. J. Teel and P.B. Aebersold. 1991. A genetic monitoring and evaluation program fro supplemented populations of salmon and steelhead in the Snake River basin. Annual report of research. National Marine Fisheries Service. Portland, Oregon.

Welsh, T. and D. Corley. 1968. Salmon and steelhead investigations. Investigations Project F 49-R-5, (1966) Job 2: salmon spawning ground surveys, Salmon River drainage, Idaho Department of Fish and Game, Boise, Idaho.

Whitesel, T.A., R.W. Carmichael, M.W. Flesher, D.L. Eddy. 1998. Summer steelhead in the Imnaha River Basin, Oregon. Pages 32-42 in Proceedings of the Lower Snake River Compensation Plan Status Review Symposium, February 3-5, 1998. Oregon Department of Fish and Wildlife, La Grande, Oregon.

Whittingham, D.G. 1980. Principles of embryo preservation. Pages. 65-83 in M. J. AshwoodSmith and J. Farrant editors. Low Temperature Preservation in Medicine and Biology. Pitman Medical Ltd., Tunbridge Wells, Kent, England. 
APPENDIX 
APPENDIX 1 
Table 5. Snake River basin chinook salmon cryopreserved from 1992-2000.

\begin{tabular}{|c|c|c|c|c|c|c|c|c|c|c|}
\hline \multirow{2}{*}{$\begin{array}{l}\text { Spawning } \\
\text { Aggregate }\end{array}$} & \multicolumn{9}{|c|}{ Number of Samples Cryopreserved, By Year } & \multirow{2}{*}{$\begin{array}{l}\text { Total \# } \\
\text { Sample } \\
\text { /Stream }\end{array}$} \\
\hline & 2000 & 1999 & 1998 & 1997 & 1996 & 1995 & 1994 & 1993 & 1992 & \\
\hline Lostine River & 18 & 2 & 3 & 2 & 3 & 1 & 4 & & & 33 \\
\hline $\begin{array}{l}\text { Lostine River } \\
\text { (captivebrood) }\end{array}$ & \multicolumn{9}{|c|}{ reported as cohort class not by spawning years } & 191 \\
\hline $\begin{array}{l}\text { Up.GrandeRonde } \\
\text { (captivebrood) }\end{array}$ & \multicolumn{9}{|c|}{ reported as cohort class not by spawning years } & 176 \\
\hline $\begin{array}{l}\text { Catherine Creek } \\
\text { (captivebrood) }\end{array}$ & \multicolumn{9}{|c|}{ reported as cohort class not by spawning years } & 223 \\
\hline Imnaha River & 71 & 95 & 79 & 41 & 33 & $43^{*}$ & $21^{*}$ & & & 383 \\
\hline Rapid River & 51 & 68 & 98 & & & & & & & 217 \\
\hline $\begin{array}{l}\text { South Fork } \\
\text { Salmon River }\end{array}$ & 54 & 93 & 45 & 45 & 19 & & & & & 256 \\
\hline Lake Creek & 15 & 6 & 3 & 4 & 3 & & & & & 31 \\
\hline Johnson Creek & 35 & 5 & 17 & 7 & & & & & & 64 \\
\hline Big Creek & 7 & 0 & 1 & 6 & 0 & 0 & 0 & 10 & 7 & 31 \\
\hline Capehorn Creek & 1 & 0 & 6 & 2 & & & & & & 9 \\
\hline Marsh Creek & 7 & 0 & 2 & 4 & & & & & & 13 \\
\hline Pahsimeroi River & 50 & 31 & & & & & & & & 81 \\
\hline $\begin{array}{l}\text { Upper Salmon } \\
\text { River }\end{array}$ & 40 & 40 & 41 & 51 & & & & & & 172 \\
\hline $\begin{array}{l}\text { Total Number of } \\
\text { Samples per year }\end{array}$ & 349 & 340 & 295 & 162 & 58 & 44 & 25 & 10 & 7 & 1880 \\
\hline
\end{tabular}

*collected and cryopreserved by Oregon Department of Fish and Wildlife 
Table 6. Snake River basin steelhead cryopreserved in 1997-2000.

\begin{tabular}{|c|c|c|c|c|c|c|c|}
\hline \multirow{2}{*}{ Spawning Aggregate } & \multicolumn{6}{|c|}{ Number of Samples Cryopreserved, By Year } & \multirow{2}{*}{$\begin{array}{l}\text { Total \# } \\
\text { Sample } \\
\text { /Stream }\end{array}$} \\
\hline & 2000 & 1999 & 1998 & 1997 & 1994 & 1993 & \\
\hline Imnaha River & 2 & & & & & & 2 \\
\hline Little Sheep Creek & 52 & 25 & 25 & 5 & & & 107 \\
\hline Grande Ronde River & 1 & & & & & & 1 \\
\hline $\begin{array}{c}\text { North Fork } \\
\text { Clearwater River } \\
\text { Dworshak Nat. Hatchery }\end{array}$ & 89 & 62 & & & & & 151 \\
\hline Selway River & & & & & $5 *$ & & 5 \\
\hline Fish Creek & 1 & & & & & $10^{*}$ & 11 \\
\hline $\begin{array}{c}\text { Snake River } \\
\text { Oxbow Hatchery }\end{array}$ & 98 & 76 & & & & & 174 \\
\hline Johnson Creek & & 2 & & & & & 2 \\
\hline $\begin{array}{c}\text { Pahsimeroi River } \\
\text { Pahsimeroi Hatchery }\end{array}$ & 40 & 47 & & & & & 87 \\
\hline Total \# Samples/year & 283 & 212 & 25 & 5 & 5 & 10 & 540 \\
\hline
\end{tabular}

*collected and cryopreserved by US Geological Survey 
Table 7. Total number of cryopreserved samples taken from Snake River basin spring / summer chinook and steelhead and the number of $0.5 \mathrm{ml}$ and $5.0 \mathrm{ml}$ straws in storage from 1992-2000.

\begin{tabular}{|c|c|c|c|c|c|}
\hline Spawning Aggregate & Species & $\begin{array}{l}\text { Number of } \\
\text { Frozen } \\
\text { Samples }\end{array}$ & $\begin{array}{l}\text { Number of } \\
0.5 \mathrm{ml} \\
\text { Straws }\end{array}$ & $\begin{array}{l}\text { Number of } \\
5.0 \mathrm{ml} \\
\text { Straws }\end{array}$ & $\begin{array}{l}\text { Total No. } \\
\text { Straws, } \\
1992-2000\end{array}$ \\
\hline Lostine River & $\mathrm{CH}$ & 33 & 768 & 90 & 858 \\
\hline Grande Ronde River & ST & 1 & 19 & 0 & 19 \\
\hline Little Sheep Creek & ST & 107 & 1,654 & 31 & 1685 \\
\hline Imnaha River & $\mathrm{CH}$ & 383 & 8,486 & 552 & 9,038 \\
\hline Imnaha River & ST & 2 & 40 & 0 & 40 \\
\hline North Fk Clearwater & ST & 147 & 2,848 & 48 & 2,896 \\
\hline Selway River & ST & 5 & 0 & 33 & 33 \\
\hline Fish Creek & ST & 11 & 60 & 117 & 177 \\
\hline Rapid River & $\mathrm{CH}$ & 211 & 5,107 & 189 & 5,296 \\
\hline South Fk Salmon R. & $\mathrm{CH}$ & 250 & 7,168 & 809 & 7,977 \\
\hline Lake Creek & $\mathrm{CH}$ & 31 & 905 & 65 & 970 \\
\hline Johnson Creek & $\mathrm{CH}$ & 64 & 2,255 & 335 & 2,590 \\
\hline Johnson Creek & ST & 2 & 30 & 0 & 30 \\
\hline Big Creek & $\mathrm{CH}$ & 31 & 1,016 & 93 & 1,109 \\
\hline Capehorn Creek & $\mathrm{CH}$ & 9 & 270 & 13 & 283 \\
\hline Marsh Creek & $\mathrm{CH}$ & 13 & 400 & 92 & 492 \\
\hline Pahsimeroi R./Hatch. & ST & 87 & 768 & 90 & 1,110 \\
\hline Pahsimeroi R./Hatch. & $\mathrm{CH}$ & 80 & 2,464 & 206 & 2,670 \\
\hline Upper Salmon River & $\mathrm{CH}$ & 172 & 5,193 & 661 & 5,854 \\
\hline Snake River, Oxbow & ST & 174 & 3,115 & 55 & 3,170 \\
\hline Totals & $\mathrm{CH}+\mathrm{ST}$ & 1,813 & 42,571 & 3,484 & 46,289 \\
\hline
\end{tabular}


Table 8. Summary of Gene Bank Fertility Experiments in 2000 at Washington State University and University of Idaho.

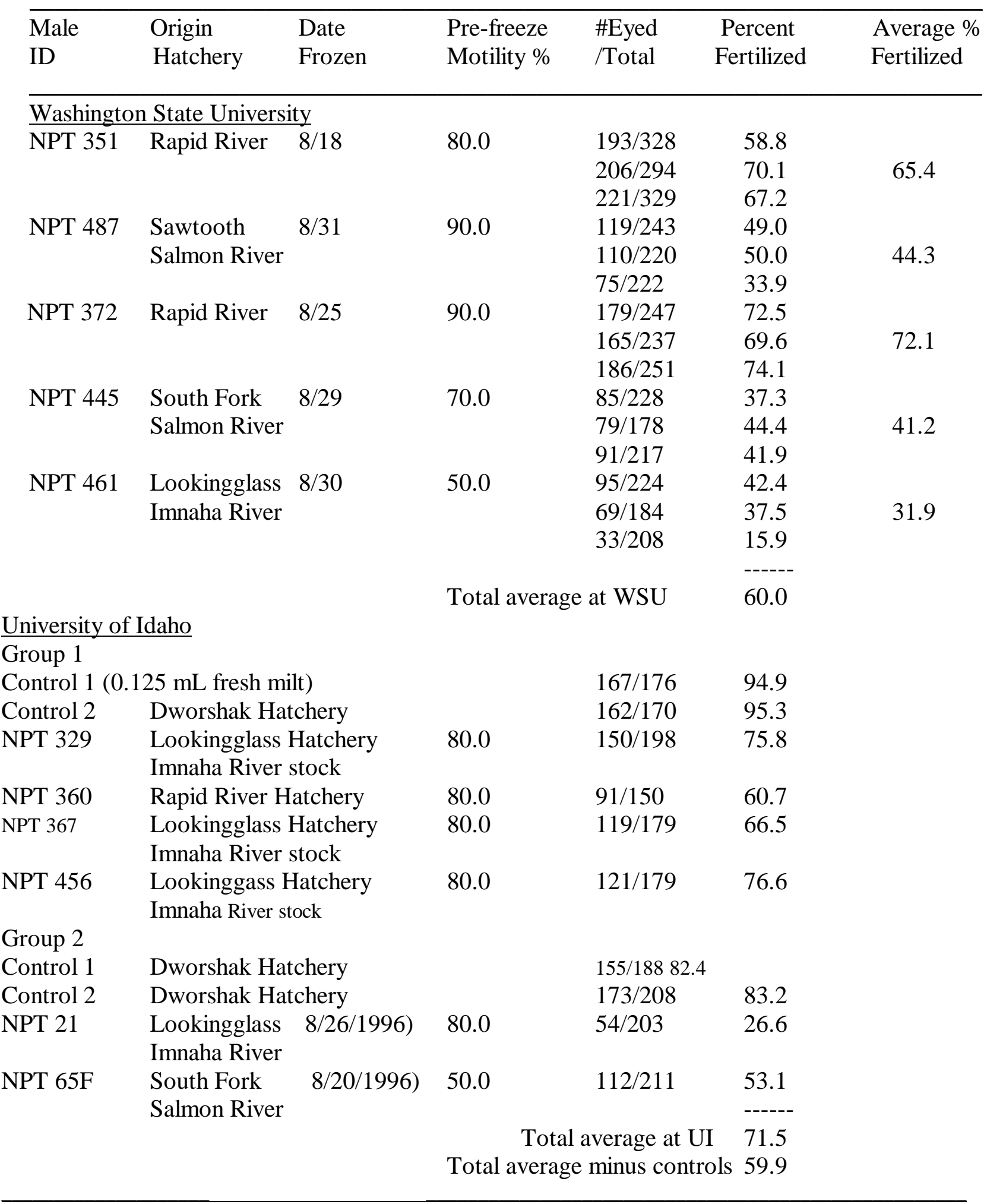


APPENDIX 2. Snake River Germplasm Repository Cryopreserved Semen Request Form 
Snake River Germplasm Repository Committee

P.O. Box 1942, 125 South Mission St

McCall, ID 83638

Phone: (208) 634-5290

Fax: (208) 634-4097

\section{Snake River Germplasm Repository Cryopreserved Semen Request Form}

Name:

Affiliation:

Phone number:

Address:

Date of request:

Date need by:

Species/stock requested:

Number of straws needed:

Hatchery or wild/natural:

Reason for request (clearly demonstrate need or type of hatchery program):

Fertilization experience using cryopreserved semen:

Name, address, and phone number of person samples should be delivered to:

Please use additional papers as necessary.

The salmon managers of the Snake River Basin are concerned with how cryopreserved samples are being used and retains the right to refuse samples for inappropriate use of the threatened salmonid species gametes. The Nez Perce Tribe can arrange to deliver and assist in the fertilization of eggs. Please call Robyn Armstrong at the McCall Field Office (address above) to coordinate transfer. The Nez Perce Tribe also may request data on the performance of the semen (percent of eggs fertilized, post-thaw sperm motility, etc.).

Signature:

Date: 
APPENDIX 3. Genetic Diversity in Oncorhynchus mykiss from the Snake River Basin and Eastern Oregon. 


\title{
GENETIC DIVERSITY IN Oncorhynchus mykiss FROM THE SNAKE RIVER BASIN AND EASTERN OREGON
}

\author{
A report to the $\mathrm{Nez}$ Perce Tribe \\ January 2001 \\ Prepared by (in alphabetic order) \\ Kim Brown, Krista Nichols, and Gary Thorgaard \\ School of Biological Sciences \\ Washington State University
}

\section{INTRODUCTION AND OVERVIEW}

The following report discusses the genetic diversity of steelhead trout (Oncorhynchus mykiss) collected by the Nez Perce Tribe for cryopreservation of male gametes in the year 2000, with comparisons made to genetic analyses completed for 1999 samples. We have utilized both mitochondrial DNA D-loop sequencing and four microsatellite loci to discern genetic diversity and the relationship among the populations of interest. The genetic markers chosen for this analysis coincide with those utilized in other population level analyses for Oncorhynchus mykiss, particularly for those aimed at differentiating steelhead and rainbow trout in California, Oregon, Washington, and Alaska (Nielsen et al., 1994a, 1994b, 1997; Wenburg et al., 1997; Nielsen and Fountain, 1999; Nielsen, 1999). These markers are putatively neutral, have higher rates of mutation than expressed genes, and thus can provide fine-level differentiation between closely related populations of organisms (Nielsen, 1999 and references therein).

Many of the $O$. mykiss sampled for this study originated from hatchery adult steelhead that returned to spawn and were captured at hatchery weirs. Included in this 2000 study are fish from Dworshak National Fish Hatchery, Oxbow Hatchery, Pahsimeroi Hatchery, Little Sheep Creek/Wallowa Hatchery in northeastern Oregon, Imnaha River in Oregon, Grande Ronde River, Fish Creek, and the Selway River (Table 1). Dworshak hatchery was established to mitigate losses of North Fork Clearwater River drainage steelhead following installation of Dworshak dam. Oxbow and Pahsimeroi are Idaho Power funded hatcheries run by Idaho Department of Fish and Game personnel to mitigate for salmon and steelhead losses due to the building of the Hells Canyon Complex of dams. Each of the hatcheries has its own unique history regarding stock establishment for hatchery populations. With this in mind, we have attempted to discuss the putative relationships of these hatchery stocks, as well as the relationship of natural Pahsimeroi River steelhead with all other populations. 
Table 1. Population information for genetic study of $O$. mykiss for the Nez Perce Tribe (99-00).

\begin{tabular}{|c|c|c|c|c|c|}
\hline Population & $\begin{array}{l}\text { Collection } \\
\text { site }\end{array}$ & $\begin{array}{l}\text { Year- } \\
\text { classes }\end{array}$ & Age & $\begin{array}{l}\text { Historical } \\
\text { makeup }\end{array}$ & $\begin{array}{l}\text { Population } \\
\text { information }\end{array}$ \\
\hline $\begin{array}{c}\text { Clearwater } \\
(\mathrm{CW}) \\
\text { Idaho }\end{array}$ & $\begin{array}{l}\text { Dworshak } \\
\text { Nat. Fish } \\
\text { Hatchery }\end{array}$ & $\begin{array}{l}1999 \\
2000\end{array}$ & $\begin{array}{l}\text { Returning } \\
\text { adults }\end{array}$ & $\begin{array}{c}\text { North Fork } \\
\text { Clearwater River }\end{array}$ & $\begin{array}{l}\text { B-run, no wild } \\
\text { fish for hatchery } \\
\text { spawning }\end{array}$ \\
\hline $\begin{array}{c}\text { Oxbow, } \\
\text { Snake River } \\
\text { (OX)Idaho }\end{array}$ & $\begin{array}{c}\text { Hells } \\
\text { Canyon } \\
\text { Dam } \\
\end{array}$ & $\begin{array}{l}1999 \\
2000\end{array}$ & $\begin{array}{l}\text { Returning } \\
\text { adults }\end{array}$ & Snake River & $\begin{array}{l}\text { Early returning } \\
\text { A- and B-run, } \\
\text { some wild fish }\end{array}$ \\
\hline $\begin{array}{c}\text { Pahsimeroi } \\
\text { (PR) } \\
\text { Idaho } \\
\end{array}$ & $\begin{array}{l}\text { Pahsimeroi } \\
\text { Hatchery, } \\
\text { river weir }\end{array}$ & $\begin{array}{l}1999 \\
2000\end{array}$ & $\begin{array}{l}\text { Returning } \\
\text { adults and } \\
\text { wild kelts } \\
\end{array}$ & Snake River & $\begin{array}{l}\text { A-run, hatchery } \\
\text { not listed, ESA- } \\
\text { listed }\end{array}$ \\
\hline $\begin{array}{c}\text { Johnson } \\
\text { Creek (JC) } \\
\text { Idaho } \\
\end{array}$ & $\begin{array}{c}\text { Johnson } \\
\text { Creek screw } \\
\text { trap (NPT) } \\
\end{array}$ & 1999 & Juvenile & $\begin{array}{c}\text { South Fork } \\
\text { Salmon River } \\
\text { Basin } \\
\end{array}$ & $\begin{array}{c}\text { Resident } \\
\text { rainbows or } \\
\text { steelhead? }\end{array}$ \\
\hline $\begin{array}{c}\text { Little Sheep } \\
\text { Creek (LSC) } \\
\text { Oregon } \\
\end{array}$ & $\begin{array}{l}\text { Wallowa } \\
\text { Hatchery }\end{array}$ & $\begin{array}{l}1999 \\
2000\end{array}$ & $\begin{array}{l}\text { Returning } \\
\text { adults }\end{array}$ & $\begin{array}{c}\text { Little Sheep } \\
\text { Creek, Imnaha } \\
\text { River } \\
\end{array}$ & $\begin{array}{l}\text { A-run, ESA- } \\
\text { listed,Very few } \\
\text { wild fish } \\
\end{array}$ \\
\hline $\begin{array}{c}\text { Imnaha River } \\
\text { (IMR) } \\
\text { Oregon }\end{array}$ & $\begin{array}{l}\text { Imnaha R. } \\
\text { screw trap } \\
\text { (NPT) - } \\
\text { lower river }\end{array}$ & 2000 & Adults & $\begin{array}{c}\text { Supplemented } \\
\text { LSCRP with Little } \\
\text { Sheep Creek } \\
\text { summer steelhead }\end{array}$ & $\begin{array}{c}\text { Summer } \\
\text { steelhead }\end{array}$ \\
\hline $\begin{array}{c}\text { Fish Creek } \\
\text { (FSH) } \\
\text { Idaho }\end{array}$ & $\begin{array}{l}\text { Fish Creek, } \\
\text { Idaho }\end{array}$ & $\begin{array}{l}1993 \\
2000\end{array}$ & $\begin{array}{l}\text { Spawning } \\
\text { adults } \\
(1993) \\
\text { Wild kelt } \\
(2000) \\
\end{array}$ & $\begin{array}{l}\text { B-run Dworshak } \\
\text { steelhead stocked } \\
\text { in } 1979,1980\end{array}$ & $\begin{array}{c}\text { Tributary to } \\
\text { Lochsa River } \\
\text { (outplants } \\
\text { through } 1982 \text { by } \\
\text { Dworshak) }\end{array}$ \\
\hline $\begin{array}{l}\text { Selway River } \\
\text { (SEL),Idaho }\end{array}$ & $\begin{array}{c}\text { Selway } \\
\text { River,Idaho }\end{array}$ & 1994 & $\begin{array}{c}\text { Spawning } \\
\text { adults }\end{array}$ & Natural stocks & $\begin{array}{l}\text { Wild and Scenic } \\
\text { River, protected }\end{array}$ \\
\hline $\begin{array}{c}\text { Home Creek } \\
(\mathrm{HC}) \\
\text { Oregon }\end{array}$ & $\begin{array}{c}\text { Home } \\
\text { Creek, SE } \\
\text { Oregon }\end{array}$ & 1999 & & $\begin{array}{l}\text { Wild redband } \\
\text { trout, Hatchery } \\
\text { stocked rainbow }\end{array}$ & \\
\hline $\begin{array}{c}\text { Blitzen River } \\
\text { (BL) } \\
\text { Oregon }\end{array}$ & $\begin{array}{l}\text { Blitzen } \\
\text { River, SE } \\
\text { Oregon }\end{array}$ & 1999 & & $\begin{array}{c}\text { Wild redband } \\
\text { trout, plus } \\
\text { Hatchery stocked } \\
\text { rainbow }\end{array}$ & \\
\hline $\begin{array}{c}\text { Three Mile } \\
\text { Creek (TM) } \\
\text { Oregon }\end{array}$ & $\begin{array}{c}\text { Three Mile } \\
\text { Creek, SE } \\
\text { Oregon }\end{array}$ & 1995 & $\begin{array}{l}\text { Spawning } \\
\text { adults }\end{array}$ & Wild redband trout & Protected \\
\hline
\end{tabular}

\section{MATERIALS AND METHODS}

\section{Tissue collection and DNA extraction}

Steelhead trout (Oncorhynchus mykiss) tissue samples were collected in Idaho and Oregon at 
collection weirs and traps during spring spawning by the Nez Perce Tribe. Fin clips or opercular punches were collected at hatcheries located on the Snake River, Pahsimeroi River, North Fork Clearwater River, Little Sheep Creek (Oregon), Johnson Creek, Imnaha River, Fish Creek, and Grande Ronde River in 2000. Additional Fish Creek and Selway River tissues were collected in 1993 and 1994, respectively. A summary of the origin and makeup of these populations is provided in Table 1. Most fish collected for this 2000 genetic analysis were of hatchery origin with the exception of all Fish Creek and Selway River samples. NPT samples were collected from February to May.

Tissues from fish obtained in 2000 were collected using either opercular punches or caudal fin clips. Tissue was immediately placed in $6 \mathrm{ml}$ tubes containing $80 \%$ ethanol for storage and shipment. Selway River and Fish Creek samples were taken from liver tissues frozen for allozyme analyses. Total genomic DNA was extracted from $1 \mathrm{~mm}^{2}$ tissue samples using the Puregene ${ }^{\circledR}$ DNA Isolation Kit D-5000A and solid tissue protocol (Gentra Systems). Extracted DNA was then quantified using the Hoefer DNA fluorometer Model TKO 100 using Hoechst dye. Samples were diluted in Tris-EDTA (TE) to 50ng/ $\mu 1$ prior to PCR amplification.

\section{Mitochondrial Sequencing}

PCR amplification of the highly variable 3' end of the mitochondrial control region was carried out using primers known to amplify this region in salmonids (Nielsen et. al., 1994, and references therein). The two primers used were S-phe (5'-GCTTTAGTTAAGCTACG-3') and P2 (5'-TGTTAAACCCCTAAACCAG-3'). The $193 \mathrm{bp}$ amplified product includes the 3' end of the control region along with $5 \mathrm{bp}$ of the adjacent phenylalanine tRNA gene. Double stranded PCR amplifications were carried out in $40 \mu$ l reactions containing $8.0 \mu \mathrm{l} 5 \mathrm{X}$ Buffer $\mathrm{C}(300 \mathrm{mM}$ Tris-HCL, $\left.75 \mathrm{mM}\left(\mathrm{NH}_{4}\right)_{2} \mathrm{SO}_{4}, 12.5 \mathrm{mM} \mathrm{MgCl} 2\right), 3.2 \mu 1$ 10mM dNTP's (2.5mM dATP, $2.5 \mathrm{mM}$ dCTP, $2.5 \mathrm{mM}$ dGTP, $2.5 \mathrm{mM}$ dTTP), $0.8 \mu \mathrm{l}$ DMSO, $6.0 \mu \mathrm{l}$ of each primer ( $4 \mathrm{pM} / \mu \mathrm{l}), 13.3 \mu \mathrm{l}$ $\mathrm{ddH}_{2} \mathrm{O}, 0.2 \mu \mathrm{Taq}$ DNA polymerase (5 U/ $\mu$ l, GibcoBRL). Amplifications were performed in an AMPLITRON $^{\circledR}$ II (Thermolyne) for 40 cycles of denaturation at $95^{\circ} \mathrm{C}$ for $50 \mathrm{~s}$, annealing at $55^{\circ} \mathrm{C}$ for $50 \mathrm{~s}$ and extension at $72^{\circ} \mathrm{C}$ for $2 \mathrm{~min} 30 \mathrm{~s}$ with a $4^{\circ} \mathrm{C}$ chill upon completion.

Amplified double stranded products $(5 \mu \mathrm{l})$ were then electrophoresed on $1 \%$ agarose gels. Gels were stained with an ethidium bromide solution and visualization of DNA was performed using UV trans-illumination. Successfully amplified products were purified using the GeneClean III (Bio 101, Inc.) for use in the second PCR reactions to produce single stranded DNA for sequencing. Single stranded DNA amplification was carried out using fluorescent dyeterminator biochemistry. The cycle sequencing reaction mixture contained $2.0 \mu$ l terminator dye

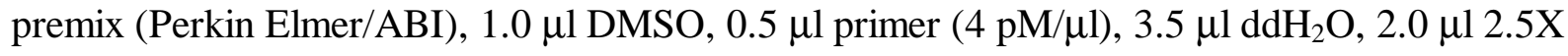
Sequence Buffer ( $5 \mathrm{mM} \mathrm{MgCl}_{2}, 200 \mathrm{mM}$ Tris- $\mathrm{HCl}$ ), and $1.0 \mu \mathrm{l}$ purified DNA for a total volume of $10.0 \mu \mathrm{l}$. Sequencing reactions were run for 25 cycles of denaturation at $96^{\circ} \mathrm{C}$ for $30 \mathrm{~s}$, annealing at $50^{\circ} \mathrm{C}$ for $15 \mathrm{~s}$, and extension at $60^{\circ} \mathrm{C}$ for $4 \mathrm{~min}$. with a $4^{\circ} \mathrm{C}$ chill upon completion. After cycle sequencing, excess unincorporated dye terminators were removed by running samples through $400 \mu \mathrm{l}$ of Sephadex G-50 in Centri-Sep spin columns (Princeton Separations, Inc.) and vacuum dried. Dried samples were resuspended in $1.0 \mu \mathrm{l}$ of loading buffer (five parts deionized formamide to one part $30 \mathrm{mg} / \mathrm{ml}$ Blue Dextran). DNA sequencing was performed on 
an ABI 377 automated sequencer using 6\% acrylamide gel. DNA sequences were assembled and analyzed using the Sequencher ${ }^{\mathrm{TM}} 3.1$ computer program (Gene Codes Corporation).

\section{Microsatellites}

Four microsatellite loci were chosen based upon their polymorphisms and use in studies of other O. mykiss populations in 1999, and have also been used in this 2000 study. Omy 77, One2, One6, and One8 were used and have been named previously according to the species in which they were isolated; Omy was isolated in O. mykiss and One were isolated in Oncorhynchus nerka. Microsatellite loci were amplified from fluorescent labeled forward and unlabeled reverse primers developed previously for Omy77 (Morris et al., 1996) and One2, One6, and One8 (Scribner et al., 1996). Omy77 and One2 were amplified in single reactions alone, while One6 and One8 were amplified in the same PCR reaction. Polymerase chain reaction (PCR) was performed in a total volume of $20 \mu \mathrm{L}$ containing $2.5 \mathrm{mM} \mathrm{MgCl} 2$ for Omy77 and One6,8 duplex or $1.5 \mathrm{mM} \mathrm{MgCl}_{2}$ for One2, 1X PCR buffer without $\mathrm{MgCl}_{2}$ (Gibco BRL), $250 \mu \mathrm{M}$ each of dATP, dCTP, dGTP, dTTP, $0.25 \mu \mathrm{L}$ of Taq DNA polymerase ( 5 units $/ \mu \mathrm{L})$, and $100 \mathrm{ng}$ of sample DNA. Primer concentrations were $0.125 \mu \mathrm{M}$ for One2, $0.05 \mu \mathrm{M}$ for One6 and $0.1 \mu \mathrm{M}$ for One8 in duplex, and $0.075 \mu \mathrm{M}$ for Omy77. The PCR profile for Omy 77 amplifications was $95^{\circ} \mathrm{C}$ for 3 minutes (pre-dwell), 35 cycles of 1 minute at $95^{\circ} \mathrm{C}$ (denature), 1 minute at annealing temperature, 2 minutes at $72^{\circ} \mathrm{C}$ (extend), followed by 5 minutes at $72^{\circ} \mathrm{C}$ (post-dwell). The annealing temperature was $50^{\circ} \mathrm{C}$ for Omy 77 . One 2 and the One6, One8 duplex were run in 'touchdown' PCR conditions with the same pre-dwell, denature, extension, and post-dwell parameters, but with the 1 minute annealing steps as follows: 2 cycles each at $62^{\circ} \mathrm{C}, 60^{\circ} \mathrm{C}$, and $58^{\circ} \mathrm{C}$ followed by 30 cycles at $55^{\circ} \mathrm{C}$ anneal.

Microsatellite alleles for each sample and locus were separated by $5 \%$ denaturing polyacrylamide gel electrophoresis on the ABI 377 Sequencing system (Perkin Elmer). Prior to gel electrophoresis, samples were diluted in deionized formamide, blue dextran dye, and Genescan ROX-500 and denatured for 2 minutes at $95^{\circ} \mathrm{C}$. Sizing of microsatellite alleles was determined with Genescan ROX-500 size standard run within each sample and analyzed with Genescan and Genotyper software (Perkin Elmer). Allele sizes in base pairs include the total size of the PCR product. Allele frequencies for each population were calculated in F-STAT (Goudet, 1999) for each locus. Observed and expected heterozygosities $\left(\mathrm{H}_{\mathrm{o}}\right.$ and $\mathrm{H}_{\mathrm{e}}$, respectively) were calculated with Genetic Data Analysis (GDA) software (Lewis and Zaykin, 1999) for each locus and over all loci for each population. Using F-STAT, alleles were randomized across populations to assess deviation from expected heterozygosity under Hardy Weinburg equilibrium. The proportions of randomizations giving larger $\mathrm{H}_{\mathrm{e}}$ than $\mathrm{H}_{\mathrm{o}}$ were calculated and are reported as significance levels for testing whether observed and expected heterozygosities are significantly different. Significance level has been set at $p=0.05$. The genetic distance between pairs of samples was calculated according to Nei (1978) and unweighted pair-group method with arithmetic mean (UPGMA) genetic distance trees were drawn in GDA. UPGMA trees were drawn with and without Fish Creek and Selway River samples (not collected in 2000). 


\section{RESULTS and DISCUSSION}

\section{Mitochondrial Haplotypes}

Using the conserved salmonid primers S-phe and P2 mitochondrial DNA of 101 samples from five populations throughout the Snake River Basin were successfully sequenced. Amplification of this highly variable 3' end of the mitochondrial control region produced a fragment 232 base pairs long including primers. This region has been studied extensively in southern steelhead by Nielsen et. al. (1994a, 1994b, 1997) and correspond to base pairs 965 to 1149 in Digby et. al. (1992) plus 5 base pairs of the adjacent phenylalanine tRNA gene. The analyzed sequence includes 193 base pairs containing seven variable sites in the studied populations. Current studies revealed three additional mitochondrial haplotypes not observed in the 1999 analysis (Table 2). One haplotype, ST21 was not observed in any 2000 samples. Maximum sequence divergence between haplotypes was $2.1 \%$ with a mean distance of $1.0 \%$ (Table 3 ). Two of the haplotypes, ST19 and ST21, are unique to the populations studied. During the 1999 study ST19 was found in populations from Little Sheep Creek, Oxbow Hatchery and Pahsimeroi River natural samples, but was only found in the Wallowa Hatchery in this analysis. Haplotype ST21 which was found in a single individual from Oxbow Hatchery in 1999 was absent for the 2000 analysis. The most common haplotype found in both years of the study was ST1, which was found in $54.5 \%$ and $65.2 \%$ of the population in 1999 and 2000, respectively. The remaining haplotype frequencies for 2000 were ST2 4.4\%, ST9 13.0\%, ST19 6.5\%, ST22 2.2\%, ST23 4.4\% and ST24 4.4\%.

Table 2. Mitochondrial Haplotype Variability for Oncorhynchus mykiss collected from the Snake and Salmon River drainages. *Numbers correspond to Digby et al., 1992. Variable nucleotide sites are shaded. ST19, ST21, ST22, ST23, and ST24 are mitochondrial haplotypes unique to study (shaded).

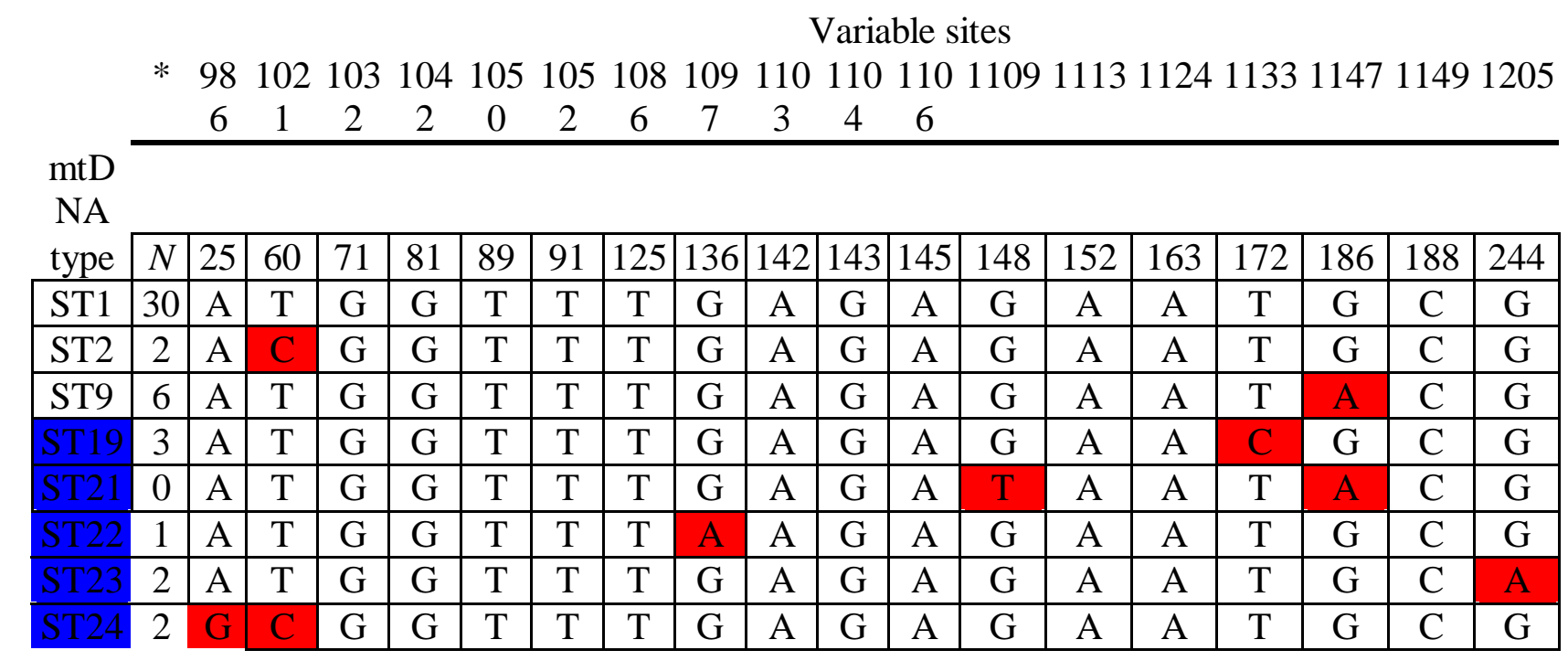


Table 3. Pairwise distance matrix for 8 steelhead mtDNA haplotypes

\begin{tabular}{ccccccccc}
$\begin{array}{c}\text { mtDNA* } \\
\text { haplotype }\end{array}$ & 1 & 2 & 9 & 19 & 21 & 22 & 23 & 24 \\
\hline 1 & - & 0.5 & 0.5 & 0.5 & 1.0 & 0.5 & 0.5 & 1.0 \\
2 & 1 & - & 1.0 & 1.0 & 1.6 & 1.0 & 1.0 & 0.5 \\
9 & 1 & 2 & - & 1.0 & 0.5 & 1.0 & 1.0 & 1.6 \\
19 & 1 & 2 & 2 & - & 1.6 & 1.0 & 1.0 & 1.6 \\
21 & 2 & 3 & 1 & 3 & - & 1.6 & 1.6 & 2.1 \\
22 & 1 & 2 & 2 & 2 & 3 & - & 1.0 & 1.6 \\
23 & 1 & 2 & 2 & 2 & 3 & 2 & - & 1.6 \\
24 & 2 & 1 & 3 & 3 & 4 & 3 & 3 & - \\
*percent sequence divergence above diagonal and number of \\
differences below diagonal
\end{tabular}

Within the 1999 studied populations mitochondrial haplotype diversity was greatest in the Oxbow Hatchery and Little Sheep Creek, with each having four mitochondrial haplotypes. Although only three haplotypes were observed in the Oxbow populations during the 2000 study, one was a new haplotype, ST22. An additional haplotype, ST24, was also found in Little Sheep Creek during the 2000 study along with the previous four haplotypes (Figure 1). The high mitochondrial haplotype diversity at these locations indicates a good representation of the source populations, provided no additional supplementation from outside sources has occurred. The inadvertent advancement of run timing at Oxbow Hatchery and the subsequent attempts to return the run to more natural timing may have altered frequency distribution for mitochondrial haplotypes. Unfortunately this cannot be determined since return rates of native fish to Hells Canyon Dam, the collection source for the hatchery, are extremely low. Comparisons of the wild and hatchery fish from Little Sheep Creek/Wallowa Hatchery may be needed to ensure the status of this ESA listed run. To ensure that the hatchery frequency distributions are representative of wild populations, sampling of wild and hatchery fish could be performed for comparison of mitochondrial haplotype frequencies.

Samples from Dworshak Hatchery contained only two mitochondrial haplotypes, ST1 and ST9 for the 1999 sample, but and additional haplotype unique to Dworshack, ST23 was observed in the 2000 study. The addition of ST23 to the 2000 study may indicate some level of year class differences in female mitochondrial haplotypes, although due to low sample size cannot be assured. This distinctive mitochondrial frequency distribution in both the 1999 and 2000 analysis is consistent with allozyme studies that have unique frequencies in this population (Williams 1994). 
Figure 1. Snake River Steelhead mtDNA Haplotypes in 2000.

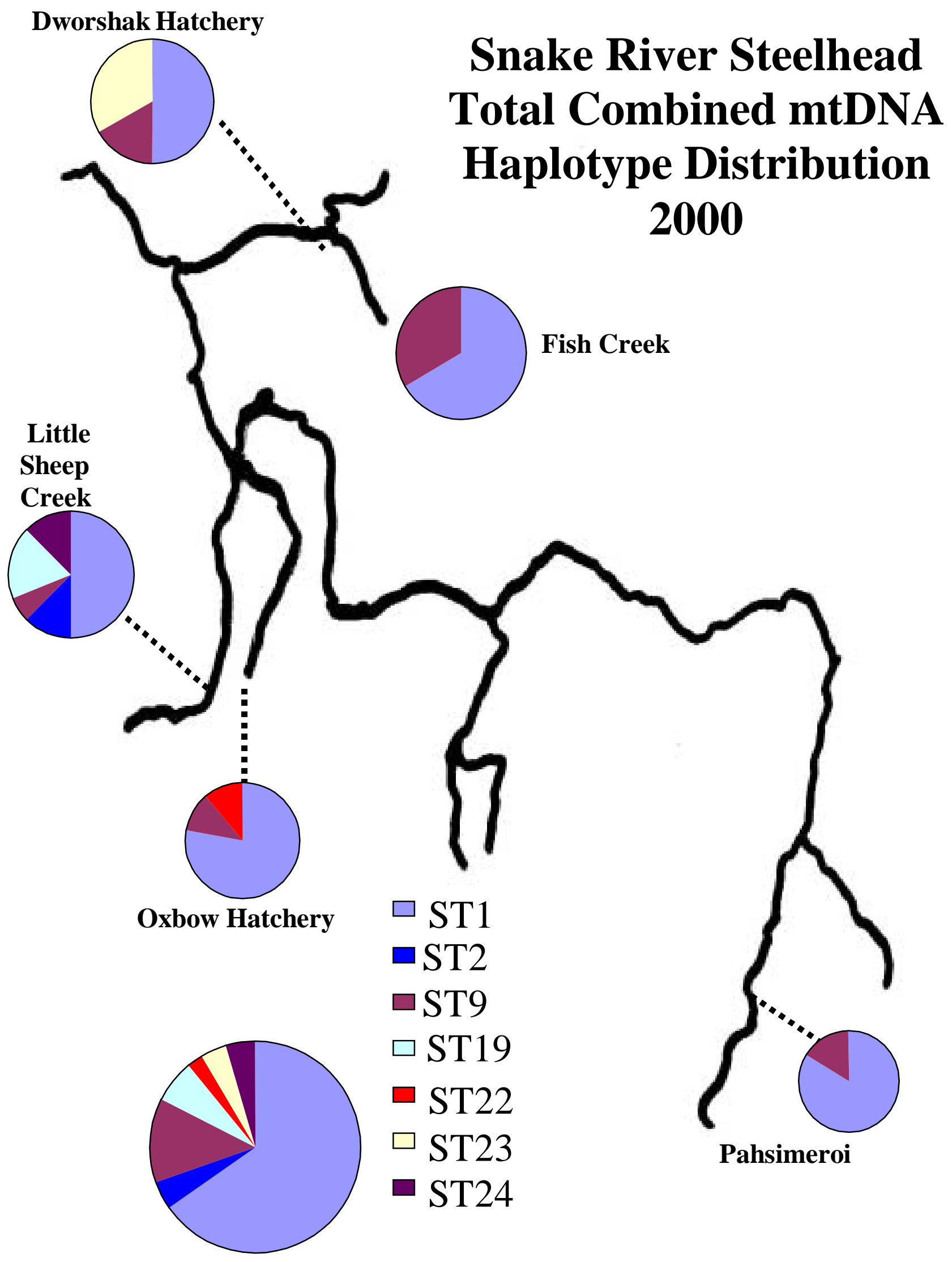


Individuals from Pahsimeroi Hatchery exhibited only two haplotypes in 2000, ST1 and ST9, with ST1 being the most frequent (83.3\%). The haplotype information for the hatchery fish is indicative of the stock collection from the Snake River. The absence of ST2 could also indicate the presence of year class differences. Sample sizes from Selway River, Imnaha River and Grande Ronde River are too small to make any conclusions as to total population haplotype frequency distribution.

\section{Microsatellites}

For comparison, Tables and Figures of 1999 data have been attached in Appendix 2. The following results will not only summarize 2000 genetic analyses, but will make comparisons to 1999 data.

For each population, allele frequencies and observed and expected heterozygosities for each microsatellite locus have been calculated (Table 4). The microsatellites chosen for this study were highly polymorphic in steelhead trout. Microsatellite diversity has been published previously for only one of the populations in this study -- the Dworshak National Fish Hatchery steelhead from the Clearwater River (Ostberg and Thorgaard, 1998). The most common allele in Ostberg and Thorgaard (1998) for the Clearwater steelhead was 254 bp for One6 and 118 or 128 bp for Omy77. In 1999, the most common allele for Clearwater steelhead for One6 was 254 bp, while the most common allele for Omy77 was 132 bp. In 2000, the most common alleles for One6 were again 254 bp, while for Omy77, the 118 bp allele was more common, similar to that in 1998. For OX, PR, and LSC (populations sampled also in 1999), generally there was an observed shift in the identity of the most common alleles between the years. The most common alleles for One 2 and One8, in fact, were not the same between years for any of the populations.

Over all loci combined, all steelhead trout populations sampled by the Nez Perce Tribe had lower observed heterozygosities than that expected assuming a random-mating, large population (Table 4). Deviation from expected heterozygosities could be indicative of inbreeding, small population sizes (and/or samples analyzed), or the presence of null microsatellite alleles. If a null or nondetected microsatellite allele exists for these populations, individuals that possess the null allele would be erroneously scored as a homozygote, thereby decreasing the value of observed heterozygosity.

The genetic distances and UPGMA distance diagrams drawn from these populations are the most informative in discerning the relationships among the Snake and Salmon River steelhead populations sampled. Nei's genetic distances (1978) calculated in this study are an expression of the probability that a randomly chosen allele from two different populations will be identical (or different in this case) relative to two randomly chosen alleles from the same population. Distance trees with the Selway River (1994) and Fish Creek (1993) samples included and excluded are depicted in Figures 2 and 3, respectively. 
Figure 2. UPGMA phenogram for Oncorhynchus mykiss from the Snake and Salmon River basins including 1993 and 1994 samples from Fish Creek and Selway River, respectively.

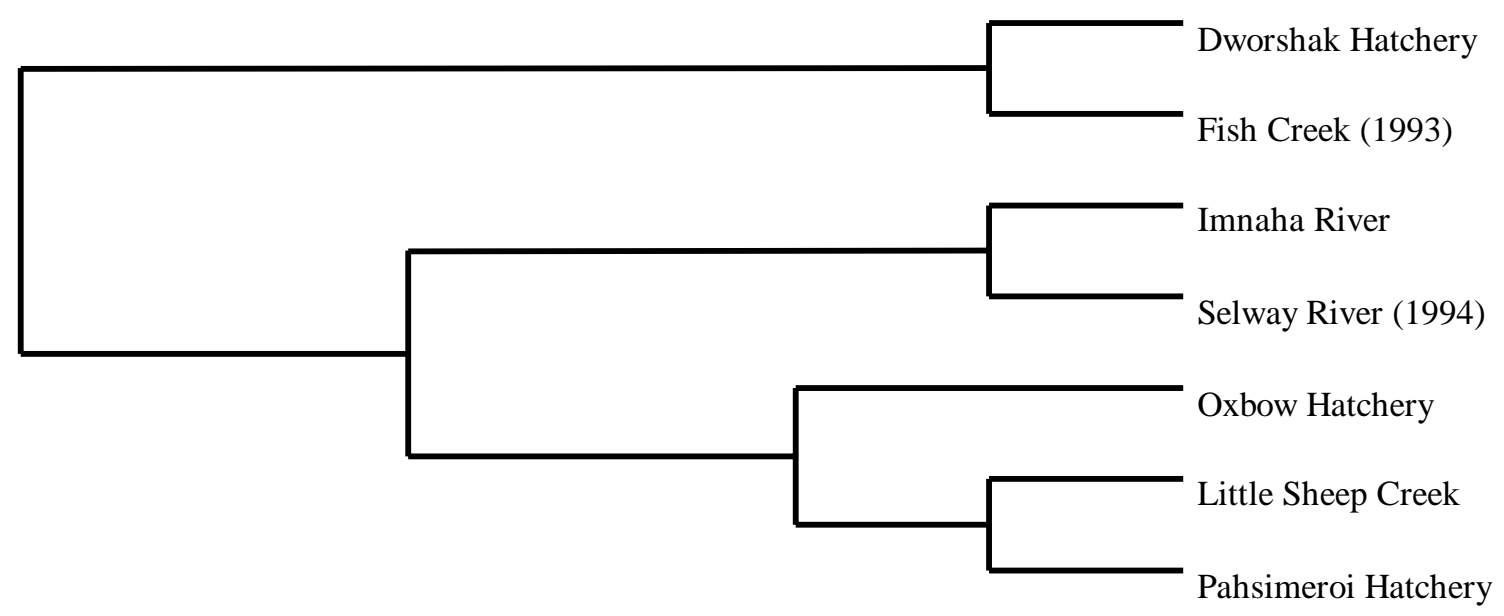

Figure 2 indicates that the Pahsimeroi River hatchery samples are most closely related to the Little Sheep Creek/Wallowa Hatchery fish, and Oxbow Hatchery fish have the next closest identity to these two groups. This is different than that reflected in the 1999 data. In 1999, Oxbow Hatchery samples were most closely related to Pahsimeroi fish. Pahsimeroi River hatchery stocks were derived from the Hells Canyon/Snake River steelhead when the Pahsimeroi hatchery opened, and it is unclear why PR fish are grouped more closely with LSC with the 2000 samples. The close relationships among LSC, OX, and PR fish relative to other drainages further implies (as with 1999 data) that the Pahsimeroi fish are more related to mainstream Snake River stocks of steelhead than they are to populations sampled in the Clearwater River drainage. Imnaha River samples (2000) were most closely related to Selway River (1994) fish, while Dworshak were most closely related to Fish Creek (1993) fish. The close distance of Fish Creek and Dworshak steelhead may be reflective of historical outplants from Dworshak. The Imnaha clade is more closely related to the Snake River stocks (Figure 3), while the Dworshak clade is most distantly related to these Snake River stocks. The Imnaha River fish, caught in the lower river are not most similar to Little Sheep Creek (Wallowa Hatchery) fish as one might expect from the history of compensation in the drainage by this hatchery. However, only two fish were collected in the Imnaha, and conclusions from this relationship should be drawn with caution. Because Fish Creek and Selway River samples (with the exception of 1 Fish Creek kelt) were sampled in years other than 2000 , we hesitate to make any conclusions about what the relationships are among these stocks.

The differences in allele frequencies for populations sampled in 1999 and 2000, together with changes in genetic distances among these populations as a reflection of these allele frequencies, suggest that there are some year-class differences in the genetic variation within and among populations. For this reason, 1993 Fish Creek and 1994 Selway River fish were removed from the UPGMA diagram in Figure 3, to better depict relationships among individuals collected only in 2000. These fish were included in this year's analysis due to our recommendation that other Salmon River and upper Snake River stocks be included in the analysis in order to determine the most probable relationships of the PR fish. Because these fish have been removed and samples 
of other river systems are unavailable for 1999 and 2000, it remains premature to make any conclusions regarding the relationships of Pahsimeroi fish to other populations in the Snake River basin.

Figure 3. Genetic distance phenogram drawn from Nei's genetic distance data for O. mykiss populations with Selway River (1994) and Fish Creek (1993) samples removed.

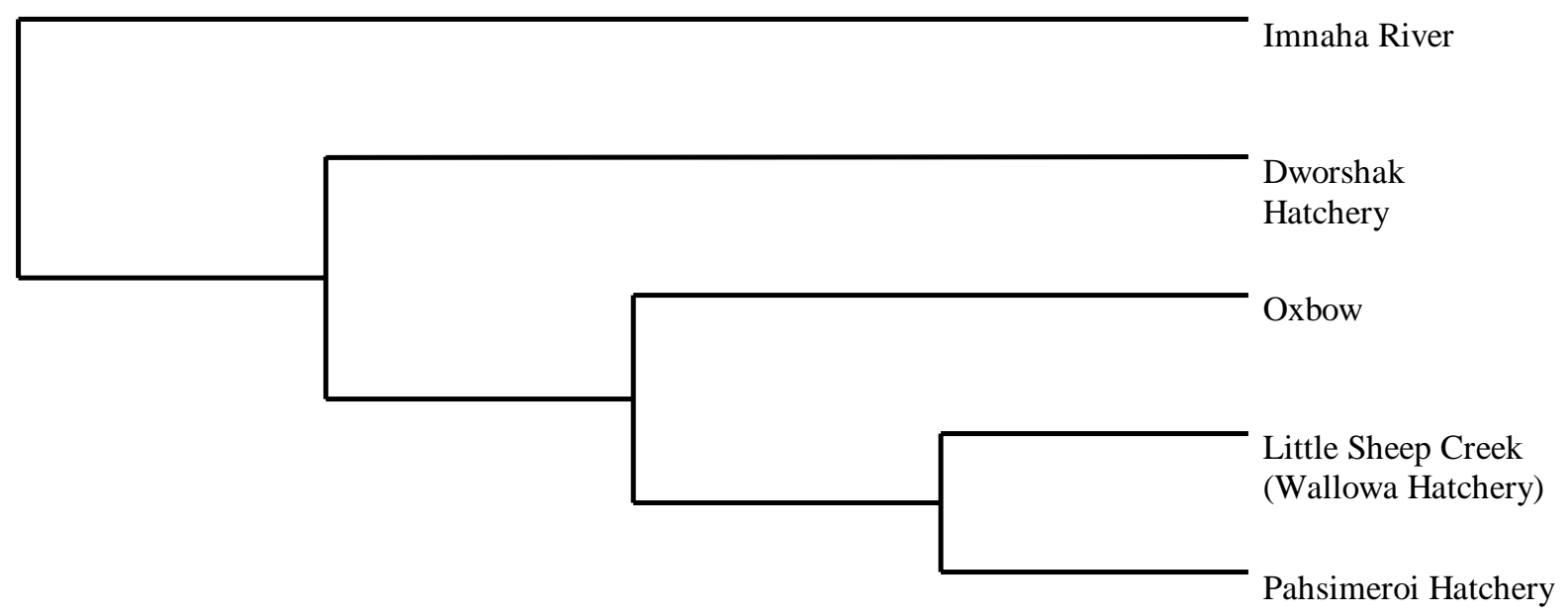

\section{Microsatellite loci reliability}

As per conversations with the Nez Perce Tribe, and among groups interested in Snake and Salmon River steelhead genetics, there is a need to prioritize sampling and standardize loci for genetic analyses. To this end, we feel that the four microsatellite loci chosen for this study have been useful, but shall comment on the reliability of each. Omy77 and One6 have been the most reliably amplified and scored. One8 is reliably amplified, but can be difficult to score due to complex patterns of stuttering. Finally, we do not recommend the long-term use of One 2 due to extreme stuttering and therefore the lesser reliability in accurate sizing of alleles for this locus. In order to determine the influence of single loci on the outcome of genetic distances among groups, UPGMA diagrams were drawn from data sets with one of the four loci removed (data not shown). The overall relationship among groups was most significantly changed when Omy77 data were removed from analyses, indicating a significant contribution of these data to the relationships among populations. However, One2, One6, and One8, when removed singly from analyses did not significantly alter the relationships among populations. We believe that the four loci chosen for these analyses accurately depict the relationship among populations, and for the objectives of this project, do not believe that the addition of more loci would significantly alter the relationships observed.

\section{Conclusions and Recommendations}

The mitochondrial DNA haplotype and microsatellite allelic distribution appear to agree on the similarities and relationships among the Snake River basin steelhead trout collected by the Nez Perce Tribe. Furthermore, both reflect differences in haplotype and allele frequencies between 1999 and 2000, indicating that there are differences in the genetic diversity of these populations between the two years. With these differences, it is difficult to make conclusions 
about the overall relationships among some stocks.

In future analyses, we would recommend the continued use of Omy77, One6, and One8 for microsatellite scoring, with possible choice of new loci that may be more reliably scored. Delineating the relationships among populations will be aided by continued sampling and similar genetic analyses over time. Although we realize the limitations in obtaining large sample sizes, especially for 'natural' fish, we feel that future efforts for genetic analyses of these populations could benefit from larger sample sizes within the same year classes for better dissection of population relationships and substructure (minimum 10 individuals).

\section{Literature cited}

Digby, T. J., M. W. Gray, and C. B. Lazier. 1992. Rainbow Trout Mitochondrial DNA: Sequence and Structural Characteristics of the Non-coding Control Region and Flanking tRNA Genes. Gene 113:197-204.

Goudet, J. 1999. FSTAT, a program to estimate and test gene diversities and fixation indices (version 2.8). Updated from Goudet (1995).

Lewis, P. O., and Zaykin, D. 1999. Genetic Data Analysis: Computer program for the analysis of allelic data. Version 1.0 (d12). Free program distributed by the authors over the internet from the GDA Home Page at http://chee.unm.edu/gda/

Morris, D.B., Richard, K.R., and J.M. Wright. 1996. Microsatellites from rainbow trout (Oncorhynchus mykiss) and their use for genetic studies of salmonids. Canadian Journal of Fisheries and Aquatic Sciences 53: 120-126.

Nei M, 1988. Molecular Evolutionary Genetics. Columbia University Press, New York.

Nielsen, J. L., C. Gan, and W. K. Thomas. 1994a. Differences in Genetic Diversity for Mitochondrial DNA between Hatchery and Wild Populations of Oncorhynchus. Canadian Journal of Fisheries and Aquatic Science 51(Suppl. 1):290-297.

Nielsen, J. L., C. A. Gan, J. M. Wright, D. B. Morris, and W. K. Thomas. 1994b. Biogeographic Distributions of Mitochondrial and Nuclear Markers for Southern Steelhead. Molecular Marine Biology and Biotechnology 3(5):281-293.

Nielsen, J. L., C. Carpanzano, M. C. Fountain, and C. A. Gan. 1997. Mitochondrial DNA and Nuclear Microsatellite Diversity in Hatchery and Wild Oncorhynchus mykiss from Freshwater Habitats in Southern California. Transactions of the American Fisheries Society 126:397-417.

Nielsen, J.L. 1999. The evolutionary history of steelhead (Oncorhynchys mykiss) along the US Pacific Coast: Developing a conservation strategy using genetic diversity. ICES Journal of Marine Science 56: 449-458. 
Nielsen, J.L. and M.C. Fountain. 1999. Microsatellite diversity in sympatric reproductive ecotypes of Pacific steelhead (Oncorhynchus mykiss) from the Middle Fork Eel River, California. Ecology of Freshwater Fish 8: 159-168.

Ostberg, C.O., and G.H. Thorgaard. 1999. Geographic distribution of chromosome and microsatellite DNA polymorphisms in Oncorhynchus mykiss native to western Washington. Copeia 2: 287-298.

Scribner, K.T., Gust, J.R., and R.L. Fields. 1996. Isolation and characterization of novel microsatellite loci: cross-species amplification and population genetic applications. Canadian Journal of Fisheries and Aquatic Sciences 53: 685-693.

Wenburg, J.K., Olsen, J.B., and P. Bentzen. 1996. Multiplexed systems of microsatellites for genetic analysis in coastal cutthroat (Oncorhynchus clarki clarki) and steelhead (Oncorhynchus mykiss). Molecular Marine Biology and Biotechnology 5(4): 273-283.

Williams, R. N. 1994. Analysis of Allozyme Variation in Snake River Steelhead Populations. Clear Creek Genetics. Meridian, ID 83642. 